University of Chicago Law School

Chicago Unbound

Journal Articles

Scholarship

2003

International Delegations, the Structural Constitution, and Non-

Self-Execution

Curtis A. Bradley

Follow this and additional works at: https://chicagounbound.uchicago.edu/journal_articles

Part of the Law Commons 


\title{
International Delegations, the Structural Constitution, and Non-Self-Execution
}

\author{
Curtis A. Bradley*
}

\begin{tabular}{|c|c|}
\hline & ...... 1557 \\
\hline I. Lin & ON DELEGATION .......................... \\
\hline A. & 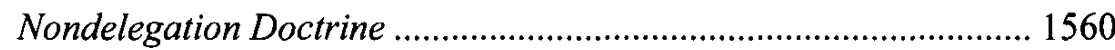 \\
\hline B. & Procedural Requirements for Making Law ................................. 1562 \\
\hline C. & 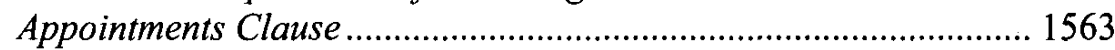 \\
\hline D. & 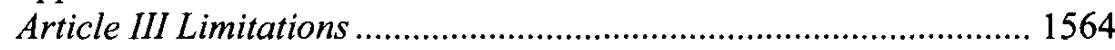 \\
\hline E. & 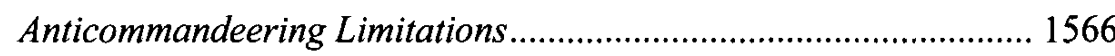 \\
\hline II. IN & NATIONAL DELEGATIONS.................. \\
\hline A. & U.N. Security Council ...................... \\
\hline B. & 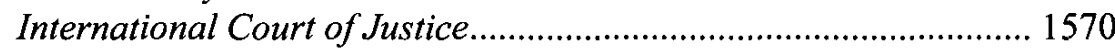 \\
\hline C. & World Trade Organization \\
\hline D. & NAFTA \\
\hline E. & Chemical Weapons Convention ................ \\
\hline F. & 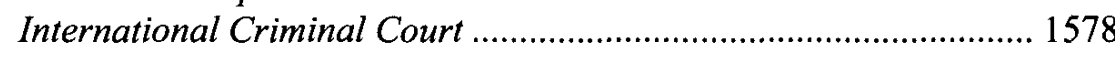 \\
\hline G. & 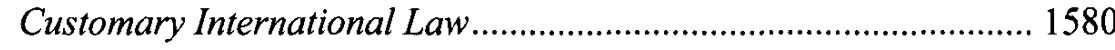 \\
\hline III. $F$ & 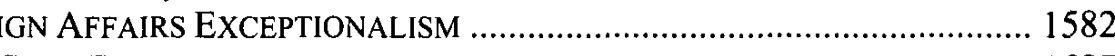 \\
\hline & 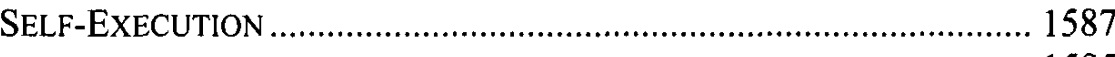 \\
\hline & \\
\hline
\end{tabular}

\section{INTRODUCTION}

In this Article, I consider some of the constitutional implications of U.S. delegations of authority to international institutions. ${ }^{1}$ Since World War II,

* Professor of Law and Hunton \& Williams Research Professor, University of Virginia. For their helpful comments and suggestions, I thank Allison Danner, Jack Goldsmith, Erica Gould, Elizabeth Magill, Mark Movsesian, Caleb Nelson, John Setear, David Sloss, Peter Spiro, Paul Stephan, Rip Verkerke, participants in a faculty workshop at the University of Virginia School of Law, participants in the June 2002 AALS Conference on Constitutional Law, and participants in the first annual workshop of the International Law in Domestic Courts section of the American Society of International Law.

1. For other general discussions of this topic, see LouIS HENKIN, FoREIGN AFFAIRS AND the United States Constitution 247-73 (2d ed. 1996); George A. Bermann, Constitutional Implications of U.S. Participation in Regional Integration, 46 AM. J. CoMP. L. 463 (supp. 1998); Lori Fisler Damrosch, "Sovereignty" and International Organizations, 3 U.C. DAVIS J. INT'L L. \& POL'Y 159 (1997); Brian F. Havel, The Constitution in an Era of Supranational Adjudication, 78 N.C. L. REV. 257 (2000); Julian G. Ku, The Delegation of 
there has been a vast growth in the number and importance of international institutions. Although some of these institutions are merely forums for discussion and negotiation, many of them exercise judicial, legislative, regulatory, investigative, or prosecutorial authority. Despite its isolationist reputation, and despite recently announcing that it would not become a party to the International Criminal Court, the United States has committed itself to many of these international institutions. By virtue of these commitments, the United States has consented to have international institutions make certain decisions, and take certain actions, that can affect the United States's rights and duties under international law and, in some instances, the enforceability of U.S. domestic law. Although the number and extent of future U.S. commitments will likely vary depending on the presidential administration, the general trend internationally - as illustrated most dramatically by developments in Europeis towards vesting ever-increasing authority in international institutions.

Without prejudging their validity, transfers of authority by the United States to international institutions could be said to raise "delegation concerns."2 These concerns relate to democratic accountability, shifts in the balance of power between the federal branches, and erosion of the U.S. system of federalism. By transferring legal authority from U.S. actors to international actors-actors that are physically and culturally more distant from, and not directly responsible to, the U.S. electorate-these delegations may entail a dilution of domestic political accountability. This accountability concern may be heightened by the lack of transparency associated with some international decisionmaking, which in turn may increase monitoring costs and the potential for what economists call "rent-seeking." 3 In addition, transfers of authority to

Federal Power to International Organizations: New Problems with Old Solutions, 85 MinN. L. REV. 71 (2000).

2. I use the phrase "delegation concerns" rather than the term "sovereignty" because the latter term is less precise and can be misleading. As Professor Henkin has noted, "in international relations, and even in international law, [sovereignty] is often a catchword, a substitute for thinking and precision." LOUIS HENKIN, INTERNATIONAL LAW: POLITICS AND VALUES 8 (1995). International law by its very nature entails a restriction on sovereignty, assuming one defines sovereignty as absolute freedom of action, yet the Constitution clearly contemplates U.S. involvement with international law. My focus here is not on the ability of the U.S. government to consent to international law restrictions, but rather on its ability to delegate decisionmaking and enforcement authority to international actors. I thus do not rely on what Professor Golove calls a "fundamental 'postulate"" against international delegations. See David Golove, The New Confederalism: Treaty Delegations of Legislative, Executive, and Judicial Authority, 55 STAN. L. REV. 1697, 1699 (2003).

3. Rent-seeking in this context refers to efforts by interest groups to obtain income transfers (broadly defined) through the regulatory process. For a discussion of the political economy of international lawmaking, and the potential for diminished accountability associated with such lawmaking, see Eric Stein, International Integration and Democracy: No Love at First Sight, 95 AM. J. INT'L L. 489 (2001); Paul B. Stephan, Accountability and International Lawmaking: Rules, Rents and Legitimacy, 17 Nw. J. INT'L L. \& BUS. 681, 693706 (1996-1997). There is a substantial literature on the "democratic deficit" in the European Union's supranational institutions. See, e.g., Lammy Betten, The Democratic 
international institutions may increase the power of one branch of the federal government relative to the others. Most typically, these transfers may increase the relative power of the executive branch, both because they often delegate the powers of other branches, and because the United States is represented in these institutions by executive branch agents. ${ }^{4}$ Finally, delegations of authority to international institutions - as with the expansion of international law more generally-have the potential to erode U.S. federalism by enhancing the power of the entire federal government vis-à-vis the states. ${ }^{5}$ Even if these effects seem relatively modest with respect to particular delegations, the cumulative effect may be more problematic. ${ }^{6}$

Although these delegation concerns are not entirely new, ${ }^{7}$ they have become much more pronounced in recent years. In the domestic context,

Deficit of Participatory Democracy in Community Social Policy, 23 EUR. L. REV. 20 (1998); Francesca E. Bignami, The Democratic Deficit in European Community Rulemaking: A Call for Notice and Comment in Comitology, 40 HARV. INT'L L.J. 451 (1999); Peter L. Lindseth, Democratic Legitimacy and the Administrative Character of Supranationalism: The Example of the European Community, 99 COLUM. L. REV. 628 (1999).

4. See, e.g., Judith Goldstein, International Law and Domestic Institutions: Reconciling North American "Unfair" Trade Laws, 50 INT'L ORG. 541 (1996) (making this point in connection with NAFTA); see also Stein, supra note 3, at 490 ("A new level of normative activity superimposed on national democratic systems makes citizen participation more remote, and parliamentary control over the executive, notoriously loose in foreign affairs matters, becomes even less effective."). Here, I speak of formal representation. Nongovernmental organizations, including organizations that have substantial U.S. membership, often participate informally in international institutions. The role of such organizations raises a different set of accountability issues. See, e.g., Essays, The Democratic Accountability of.Non-Governmental Organizations, 3 CHI. J. INT'L L. 155 (2002).

5. For discussion of how the expansion of international law has the potential to erode U.S. federalism, see Curtis A. Bradley, The Treaty Power and American Federalism, 97 Mich. L. Rev. 390, 402-09 (1998); Barry Friedman, Federalism's Future in the Global Village, 47 VAND. L. REV. 1441 (1994).

6. Cf. Youngstown Sheet \& Tube Co. v. Sawyer, 343 U.S. 579, 594 (1952) (Frankfurter, J., concurring) ("The accretion of dangerous power does not come in a day. It does come, however slowly, from the generative force of unchecked disregard of the restrictions that fence in even the most disinterested assertion of authority.").

7. Delegation concerns were raised with respect to the 1794 Jay Treaty, which, among other things, called for the establishment of several bilateral arbitration commissions, including a commission to resolve claims by British creditors. See Treaty of Amity, Commerce and Navigation, Nov. 19, 1794, U.S.-Gr. Brit., 8 Stat. 116 [hereinafter Jay Treaty]; David P. CurRie, The Constitution IN Congress: The Federalist Period, 1789 1801 , at 212 n.46 (1997). In the early 1900s, U.S. negotiators raised delegation concerns with respect to a proposed international court that would have had the power to review the prize decisions of national courts. See QUINCY Wright, THE CONTROL OF AMERICAN FOREIGN RELATIONS 117-18 (1922). In 1911, the Senate Foreign Relations Committee argued that it would be unconstitutional to delegate to international arbitration commissions the authority to determine the scope of their own jurisdiction. See Charles CheneY Hyde, INTERNATIONAL LAW: CHIEFLY AS INTERPRETED AND APPLIED BY THE UNITED STATES $§ 504$, at 24-25 (1922). And, in negotiating the structure of the proposed International Labour Organization in 1919, U.S. delegates argued against granting the organization the power to 
similar concerns about accountability and aggrandizement of power are addressed by a variety of separation of powers and federalism doctrines. I will argue in this Article that, whether viewed from a formal or functional perspective, these structural constitutional doctrines are relevant to international delegations. ${ }^{8}$ I will also argue that at least some of the constitutional concerns associated with these delegations can be addressed by presuming that the decisions and actions of international institutions are "nonself-executing"- that is, that they do not create enforceable federal law within the United States unless and until they are implemented by Congress. As I will explain, this has in fact been the approach intuitively followed by U.S. courts in recent years when confronted with delegation concerns, and it also is an approach increasingly mandated by the U.S. treatymakers and Congress.

This Article proceeds in four Parts. Part I provides a brief overview of some of the constitutional doctrines that may be relevant to international delegations. Part II describes a variety of actual and potential delegations of authority by the United States to international institutions and explains how these delegations may raise constitutional concerns. Part III argues that these constitutional concerns are not eliminated simply because international delegations involve foreign rather than domestic affairs. Part IV explains how a non-self-execution approach to international delegations will reduce at least some of these constitutional concerns.

\section{LIMITS ON DELEGATION}

In this Part, I briefly describe some of the limitations that the Constitution imposes on delegations of authority. Although the decisions applying these limitations have generally involved domestic delegations, both the formal terms of these limitations and their functional underpinnings appear to be relevant to international delegations.

\section{A. Nondelegation Doctrine}

In thinking about constitutional limits on delegation, a natural starting point is the so-called "nondelegation doctrine." The Supreme Court has stated that "Congress generally cannot delegate its legislative power to another

create binding labor standards, on the ground that this power would improperly allow the organization to impose new treaty obligations on the United States without going through the treaty process specified in the United States Constitution. See Pittman B. Potter, Inhibitions upon the Treaty-Making Power of the United States, 28 AM. J. INT'L L. 456, 456-57 (1934).

8. I do not consider here whether the standard formal/functional distinction is a useful way of thinking about structural constitutional issues. For criticism of this distinction in the context of separation of powers law, see M. Elizabeth Magill, Beyond Powers and Branches in Separation of Powers Law, 150 U. PA. L. REV. 603 (2001); M. Elizabeth Magill, The Real Separation in Separation of Powers Law, 86 VA. L. REV. 1127 (2000). 
Branch."9 The "fundamental precept" of this nondelegation doctrine, the Court has said, is that "the lawmaking function belongs to Congress . . . and may not be conveyed to another branch or entity."10 In other words, the Court has construed the Constitution's grant of legislative powers to Congress as implicitly precluding the transfer of these powers to other actors. At least in theory, the nondelegation doctrine "forces a politically accountable Congress to make the policy choices, rather than leave this to unelected administrative officials."11 Under this doctrine, when Congress delegates power, it must "lay down by legislative act an intelligible principle to which the person or body authorized to [act] . . . is directed to conform."12

Although the policy concerns underlying the nondelegation doctrine (such as the concern about accountability) might seem relevant to international delegations, the doctrine, as currently applied by the Supreme Court, may be too weak to impose any meaningful restraint on such delegations. Despite professing its commitment to the doctrine, the Court has allowed Congress to delegate substantial interpretive and regulatory authority to both the executive branch and the judiciary, and it has not found a violation of the intelligible principle requirement since the mid-1930s. ${ }^{13}$ The Court has explained that its nondelegation doctrine "has been driven by a practical understanding that in our increasingly complex society, replete with ever changing and more technical problems, Congress simply cannot do its job absent an ability to delegate power under broad general directives."14 Although some Supreme Court Justices and academic commentators have called for reinvigorating the nondelegation doctrine, the Court has not yet shown an inclination to do so. ${ }^{15}$

This assessment turns out to be incomplete, however, for two reasons. First, as other scholars have noted, nondelegation concerns have often

9. Mistretta v. United States, 488 U.S. 361, 372 (1989) (citation omitted).

10. Loving v. United States, 517 U.S. 748, 758 (1996). (1997).

11. Erwin Chemerinsky, Constitutional Law: Principles and Policies 235

12. J.W. Hampton, Jr. \& Co. v. United States, 276 U.S. 394, 409 (1928).

13. See Panama Refining Co. v. Ryan, 293 U.S. 388 (1935); A.L.A. Schechter Poultry Corp. v. United States, 295 U.S. 495 (1935).

14. Mistretta, 488 U.S. at 372.

15. See, e.g., Whitman v. Am. Trucking Ass'ns, 531 U.S. 457 (2001) (finding that broad delegation of authority to the Environmental Protection Agency satisfied the "intelligible principle" requirement). For recent academic discussion of the nondelegation doctrine, compare Gary Lawson, Delegation and Original Meaning, 88 VA. L. REV. 327 (2002) (arguing that Founding history and enumerated powers structure of the Constitution supports a nondelegation doctrine), with Eric A. Posner \& Adrian Vermeule, Interring the Nondelegation Doctrine, 69 U. CHI. L. REV. 1721 (2002) (arguing that there is no constitutional support for the nondelegation doctrine). See also Symposium, The Phoenix Rises Again: The Nondelegation Doctrine from Constitutional and Policy Perspectives, 20 CARDozo L. REV. 731 (1999). 
influenced the Court's construction of statutes. ${ }^{16}$ Thus, the Court has sought to promote the policies underlying the doctrine indirectly through interpretation, rather than directly through constitutional invalidation. As discussed below, there may be arguments for similarly addressing constitutional concerns with respect to international delegations by means of interpretation rather than by direct constitutional review.

Second, there are a number of other separation of powers doctrines that impose limits on delegations of authority and which, unlike the nondelegation doctrine, are directly enforced by the Supreme Court. As discussed below, at least some of these doctrines appear to be relevant to international delegations.

\section{B. Procedural Requirements for Making Law}

The Constitution's procedural requirements for making law have been construed to limit delegations of authority. Thus, for example, the Supreme Court has disallowed delegations that appear to bypass the Constitution's bicameralism and presentment requirements for federal legislation. ${ }^{17}$ In doing so, the Court has made clear that "the fact that a given law or procedure is efficient, convenient, and useful in facilitating functions of government, standing alone, will not save it if it is contrary to the Constitution."18 The Court has enforced these bicameralism and presentment requirements not only with respect to horizontal delegations of authority between the federal branches, but also with respect to a vertical delegation of authority to an entity created under state law. ${ }^{19}$ As the Court explained in Metropolitan Washington Airports Authority, "[a]ny other conclusion would permit Congress to evade the 'carefully crafted' constraints of the Constitution... simply by delegating primary responsibility for execution of national policy to the States." 20 As with federal legislation, there are procedural requirements specified in the Constitution for making treaties - most notably the requirements of senatorial consent and presidential ratification-and these requirements may similarly impose limits on delegation.

16. See John F. Manning, The Nondelegation Doctrine as a Canon of Avoidance, 2000 Sup. CT. REV. 223; Cass R. Sunstein, Nondelegation Canons, 67 U. CHI. L. REv. 315 (2000).

17. See, e.g., Clinton v. City of New York, 524 U.S. 417 (1998) (invalidating Line Item Veto Act); INS v. Chadha, 462 U.S. 919 (1983) (invalidating legislative veto provision).

18. Chadha, 462 U.S. at 944.

19. See Metro. Wash. Airports Auth. v. Citizens for the Abatement of Aircraft Noise, Inc., 501 U.S. 252, 275-76 (1991).

20. Id. at 269-70 (quoting Chadha, 462 U.S. at 959). 


\section{Appointments Clause}

The Article II Appointments Clause also has been read to limit delegations. This clause gives the President the power to appoint, with the advice and consent of the Senate, ambassadors, other public ministers and consuls, Supreme Court Justices, and all other "Officers of the United States" whose appointment is not otherwise provided for in the Constitution. ${ }^{21}$ The Clause also states that Congress may vest the appointment of "inferior Officers" in either the President, the courts, or in the heads of departments. ${ }^{22}$ The Supreme Court has made clear that "[u]nless their selection is elsewhere provided for [in the Constitution], all officers of the United States are to be appointed in accordance with the Clause." 23 The Court also has stated that "any appointee exercising significant authority pursuant to the laws of the United States is an 'Officer of the United States,' and must, therefore, be appointed in the manner prescribed" by the clause. ${ }^{24}$ As discussed below, it is conceivable that some international officials will fall within this definition.

In addition to potentially falling within the formal terms of the Appointments Clause, international delegations may also implicate the functional policies of the clause. The requirements of the clause, the Supreme Court has explained, are designed both to prevent aggrandizement of power by one branch at the expense of another and to ensure public accountability in the appointments process. ${ }^{25}$ According to the Court, the clause "reflects the Framers' conclusion that widely distributed appointment power subverts democratic government." 26 Thus, even when there is no interference with executive branch prerogatives, the clause "prevents Congress from dispensing power too freely; it limits the universe of eligible recipients of the power to appoint."27 Furthermore, the Court has stated that the requirements of the Appointments Clause cannot be waived by either Congress or the executive branch because the interests protected by the clause "are not those of any one branch of Government but of the entire Republic."28 The "entire Republic['s]" interests may similarly be implicated by international delegations.

21. U.S. CONST. art. II, $\S 2$, cl. 2.

22. Id.

23. Buckley v. Valeo, 424 U.S. 1, 132 (1976).

24. Id. at 126. The Court has held that the Clause does not apply, however, to "employees," which the Court has defined as "lesser functionaries subordinate to officers of the United States." Id. at 126 n.162.

25. See, e.g., Edmond v. United States, 520 U.S. 651, 660 (1997); Ryder v. United States, 515 U.S. 177, 182 (1995); Freytag v. Commissioner, 501 U.S. 868, 878, 884 (1991).

26. Freytag, 501 U.S. at 885 .

27. Id. at 880 .

28. Id. The Court also has invalidated delegations that appear to infringe on the President's implied power to remove executive officers. See, e.g., Bowsher v. Synar, 478 U.S. 714, 726 (1986) (disallowing assignment of certain powers to Comptroller General on 


\section{Article III Limitations}

The procedural safeguards in Article III of the Constitution also have been interpreted to limit delegations. Article III states that "[t]he judicial Power of the United States, shall be vested in one supreme Court, and in such inferior Courts as the Congress may from time to time ordain and establish."29 Additionally, it specifies that the federal judicial power is to be exercised by judges who "shall hold their Offices during good Behaviour, and [who] shall, at stated Times, receive for their Services a Compensation, which shall not be diminished during their Continuance in Office." 30 This language has been interpreted as at least sometimes precluding the vesting of the judicial power of the United States in tribunals that are not ordained and established by Congress and that do not have Article III tenure and salary protections. This limitation may be relevant to international adjudicatory tribunals, which, of course, are not established pursuant to Article III. ${ }^{31}$

To be sure, the Supreme Court has not provided clear guidance regarding the circumstances under which non-Article III tribunals will be deemed unconstitutional. Although the Court invalidated an important piece of bankruptcy reform legislation on the ground that it unconstitutionally delegated judicial power to non-Article III tribunals, ${ }^{32}$ there was no majority opinion in that case, and the Court's holding was limited to the narrow proposition that "Congress may not vest in a non-Article III court the power to adjudicate, render final judgment, and issue binding orders in a traditional contract action arising under state law, without consent of the litigants, and subject only to ordinary appellate review." 33 In subsequent decisions, the Court has attempted to assess, on a case-by-case basis, "the extent to which a given congressional decision to authorize the adjudication of Article III business in a non-Article III tribunal impermissibly threatens the institutional integrity of the Judicial Branch." 34 In doing so, the Court has considered a number of factors, including:

the extent to which the "essential attributes of judicial power" are reserved to Article III courts, and, conversely, the extent to which the non-Article III forum exercises the range of jurisdiction and powers normally vested only in Article III courts, the origins and importance of the right to be adjudicated,

the ground that "Congress cannot reserve for itself the power of removal of an officer charged with the execution of the laws except by impeachment").

29. U.S. CONST, art. III, $\S 1$.

30. Id.

31. See, e.g., Sandra Day O'Connor, Federalism of Free Nations, 28 N.Y.U. J. INT'L L. \& POL. 35, 36-42 (1995) (raising the possibility that the vesting of decisionmaking authority in international tribunals would violate Article III).

32. See N. Pipeline Constr. Co. v. Marathon Pipe Line Co., 458 U.S. 50 (1982).

33. Thomas v. Union Carbide Agric. Prods. Co., 473 U.S. 568, 584 (1985) (citation omitted).

34. Commodity Futures Trading Comm'n v. Schor, 478 U.S. 833, 851 (1986). 
and the concerns that drove Congress to depart from the requirements of Article III. ${ }^{35}$

The key points for present purposes are that the Court has interpreted Article III as imposing a limitation on the vesting of judicial power in non-Article III tribunals, and that the Court has shown a willingness to enforce this limitation, even if on a somewhat unpredictable, case-by-case basis.

In addition to limiting the use of non-Article III tribunals, Article III's reference to the "judicial Power" precludes at least some forms of review of federal court decisions by non-Article III officials. An early Supreme Court case, Hayburn's Case, ${ }^{36}$ has come to stand for the proposition that Congress may not vest review of the decisions of Article III courts in officials of the executive branch. That case involved a 1792 statute that authorized pensions for disabled veterans of the Revolutionary War. The statute provided that the federal circuit courts were to determine the appropriate disability payments, but that the Secretary of War had the discretion either to adopt or reject the courts' findings. The Supreme Court did not address the constitutionality of this arrangement, but the views of several circuit courts (reflecting the views of five of the six Supreme Court Justices) were reported with the case, and these courts reasoned that the statute was unconstitutional because it asked the federal courts to do something that was not judicial in nature, and because, by subjecting judicial determinations to executive branch review, it threatened the independence of the federal judiciary. ${ }^{37}$ One can imagine similar concerns being raised with respect to the review of U.S. judicial decisions by international institutions, where the only U.S. representative is an executive branch agent. 38

35. Id. (citations omitted).

36. 2 U.S. (2 Dall.) 408 (1792).

37. See id. at 410-14. The views of the remaining Supreme Court Justice (Johnson) were not reported with the case, but he too had ruled that he could not "constitutionally take Cognizance of and determine on the said Petitions." See Susan Low Bloch, The Early Role of the Attorney General in Our Constitutional Scheme: In the Beginning There Was Pragmatism, 1989 DukE L.J. 561, 592 n.102 (describing and citing Johnson's decision); see also Miller v. French, 530 U.S. 327, 343 (2000) (stating that [Hayburn's Case] "'stands for the principle that Congress cannot vest review of the decisions of Article III courts in officials of the Executive Branch"' (quoting Plaut v. Spendthrift Farm, Inc., 514 U.S. 211, 218 (1995))). Hayburn's Case is also frequently cited for the broader proposition that the federal courts may not issue advisory opinions.

38. Some of the Justices in the decisions reported in Hayburn's Case suggested that nonjudicial duties could be assigned to federal judges acting individually rather than as part of an Article III court. See 2 U.S. (2 Dall.) at 410 n.1 (Jay, C.J. \& Cushing, J.). The full Court later endorsed that suggestion in a case involving a claims settlement procedure established by Congress as part of its implementation of a treaty with Spain. See United States v. Ferreira, 54 U.S. (13 How.) 40, 50-51 (1851). Based in part on that reasoning, the Court held in 1989 that it was not unconstitutional for federal judges to serve on the United States Sentencing Commission, which promulgated the U.S. Sentencing Guidelines. See Mistretta v. United States, 488 U.S. 361, 402-08 (1989); see also Lo Duca v. United States, 93 F.3d 1100 (2d Cir. 1996) (upholding constitutionality of the federal extradition statute, 
The Supreme Court also has held, in Plaut v. Spendthrift Farm, Inc., ${ }^{39}$ that Congress does not have the power to reopen, retroactively, a federal court's final judgment in a civil case. In that case, Congress had authorized the reinstitution of certain lawsuits that had been dismissed on statute-oflimitations grounds. Analogizing to Hayburn's Case, the Court held that Congress's reopening of a final judgment unconstitutionally interferes with the power of the federal courts to decide cases, in violation of Article III of the Constitution and principles of separation of powers..$^{40}$ The Constitution, reasoned the Court,

gives the Federal Judiciary the power, not merely to rule on cases, but to decide them, subject to review only by superior courts in the Article III hierarchy-with an understanding, in short, that "a judgment conclusively resolves the case" because "a 'judicial Power' is one to render dispositive judgments."4l

Again, this concern with protecting the integrity of the federal judicial process is potentially relevant to international delegations.

\section{E. Anticommandeering Limitations}

Some aspects of the Supreme Court's federalism jurisprudence may also limit delegations of authority. Most notably, the Court has held that Congress may not "commandeer" state legislatures or executive branch officials to implement federal regulatory programs. ${ }^{42}$ In addition to finding that such commandeering violates the "dual sovereignty" implicit in the Constitution, the Court has explained that commandeering undermines political accountability, because "it may be state officials who will bear the brunt of public disapproval, while the federal officials who devised the regulatory program may remain insulated from the electoral ramifications of their decision." 43 The Court also has expressed concern that such commandeering could allow Congress to implement federal law without the assistance of the President, thereby

pursuant to which federal judges and magistrate judges issue certificates of extraditability that are reviewable by the Secretary of State).

39. 514 U.S. 211 (1995).

40. Id. at $225-26$.

41. Id. at 218-19 (quoting Frank Easterbrook, Presidential Review, 40 CASE W. RES. L. REV. 905, 926 (1990)). The Court also suggested, however, that Congress may have broad authority to enact prospective rules that limit the finality of judgments. See id. at 234-35. In addition, the Court apparently will allow Congress to reopen a final judgment when the judgment is in favor of the United States. See id. at 230-31 (discussing United States v. Sioux Nation, 448 U.S. 371 (1980)).

42. See Printz v. United States, 521 U.S. 898 (1997); New York v. United States, 505 U.S. 144 (1992). To the delight of comparative constitutionalists, Justice Breyer's dissent in Printz refers to the constitutional practices of other federal systems in arguing that some commandeering should be allowed. See Printz, 521 U.S. at 976-77 (Breyer, J., dissenting).

43. New York, 505 U.S. at 169. 
enhancing its power vis-à-vis the executive branch. ${ }^{44}$ Among other things, these anticommandeering decisions confirm that the Court's concerns about accountability and aggrandizement of power extend beyond horizontal delegations of authority between the federal branches. ${ }^{45}$

There is of course substantial academic and judicial debate about the validity and scope of the above doctrines. Importantly, however, the Supreme Court and most academic commentators believe that the Constitution imposes some restraints on governmental delegations of authority in order to preserve accountability and limit aggrandizements of power. Although most of the cases in which the Court has applied these constitutional limits have involved horizontal delegations of authority between federal branches, the logic of the Court's analysis would suggest-and the Court has sometimes expressly confirmed-that these limits are also relevant to vertical delegations of authority. 46

\section{INTERNATIONAL DELEGATIONS}

Whether applied in a formal way (with an emphasis on constitutional text, structure, and history) or in a functional way (with an emphasis on the underlying policy concerns and the practical effect of the delegation), some of

44. See Printz, 521 U.S. at 923 n. 12.

45. The above examples are not the only separation of powers and federalism limits enforced by the Supreme Court. For example, the Court has long enforced Article III "case or controversy" requirements. See, e.g., Raines v. Byrd, 521 U.S. 811 (1997) (standing); Marbury v. Madison, 5 U.S. (1 Cranch) 137 (1803) (scope of original jurisdiction). In recent years, the Court also has imposed limits on the scope of Congress's Article I and 14th Amendment powers. See, e.g., United States v. Morrison, 529 U.S. 598 (2000); City of Boerne v. Flores, 521 U.S. 507 (1997); United States v. Lopez, 514 U.S. 549 (1995). Furthermore, the Court has imposed limits on the federal government's ability to override state sovereign immunity. See, e.g., Kimel v. Fla. Bd. of Regents, 528 U.S. 62 (2000); Alden v. Maine, 527 U.S. 706 (1999); Seminole Tribe v. Florida, 517 U.S. 44 (1996). While it is possible to imagine ways in which these limits would be relevant to international delegations, they will generally be less relevant than the examples discussed in the text.

46. Because my focus is on U.S. constitutional principles, I do not address here the desirability of international delegations from the perspective of general moral or political theory. Nor do I consider the comparative lessons that might be drawn from international delegations made by other governments. If such a comparison were to inform the U.S. constitutional analysis, one would need to know the extent to which the other governments had structural constitutional principles similar to those of the United States. The same point presumably holds with respect to efforts to analogize to delegations of power made by the state governments under the Articles of Confederation. See generally Golove, supra note 2 (analogizing to those delegations). 
the above doctrines are likely to be implicated by U.S. participation in international institutions. ${ }^{47} \mathrm{~A}$ variety of examples illustrate this point.

\section{A. U.N. Security Council}

The United Nations Security Council, which was established pursuant to the United Nations Charter, consists of five permanent members (the United States, Russia, Great Britain, France, and China) and ten rotating nonpermanent members. Under the Charter (a treaty that has now been ratified by almost all nations in the world), the Security Council is charged with "primary responsibility for the maintenance of international peace and security." 48 If it determines that there is a threat to international peace, the Security Council may authorize the imposition of a variety of nonmilitary sanctions, including "complete or partial interruption of economic relations and of rail, sea, air, postal, telegraphic, radio, and other means of communication, and the severance of diplomatic relations." 49 If it determines that nonmilitary measures "would be inadequate or have proved to be inadequate," the Council can authorize "such action by air, sea, or land forces as may be necessary to maintain or restore international peace and security." 50 The Charter obligates each member, including the United States, to "accept and carry out the decisions of the Security Council in accordance with the present Charter."5I

47. U.S. participation in international institutions is typically accomplished by means of a treaty or congressional-executive agreement and thus may also implicate issues relating to the scope of the treaty power. For that debate, compare Bradley, supra note 5 (arguing in favor of federalism limitations), and Curtis A. Bradley, The Treaty Power and American Federalism, Part II, 99 MICH. L. REV. 98 (2000) (same), with David M. Golove, TreatyMaking and the Nation: The Historical Foundations of the Nationalist Conception of the Treaty Power, $98 \mathrm{MICH}$. L. REV. 1075 (2000) (arguing against federalism limitations). See also Edward T. Swaine, Does Federalism Constrain the Treaty Power?, 103 CoLUM. L. REV. 403 (2003). International institutions established by congressional-executive agreement also implicate the debate over the legitimacy of using such agreements in lieu of Article II treaties. For that debate, compare Bruce Ackerman \& David Golove, Is NAFTA Constitutional?, 108 HARV. L. Rev. 799 (1995), and David M. Golove, Against Free-Form Formalism, 73 N.Y.U. L. REV. 1791 (1998), with Laurence H. Tribe, Taking Text and Structure Seriously: Reflections on Free-Form Method in Constitutional Interpretation, 108 HARV. L. REV. 1221 (1995). See also Joel R. Paul, The Geopolitical Constitution: Executive Expediency and Executive Agreements, 86 CAL. L. ReV. 671 (1998); Peter J. Spiro, Treaties, Executive Agreements, and Constitutional Method, 79 TEX. L. REV. 961 (2001); John C. Yoo, Laws as Treaties?: The Constitutionality of Congressional-Executive Agreements, 99 MICH. L. REV. 757 (2001); $c f$. Made in the USA Found. v. United States, 242 F.3d 1300 (11 th Cir. 2001) (dismissing challenge to the constitutionality of the NAFTA congressionalexecutive agreement based on political question doctrine).

48. U.N. ChARTER, art. 24, para. 1.

49. Id. art. 41.

50. Id. art. 42 .

51. Id. art. 25. 
There has long been debate among constitutional law scholars about the distribution of war powers between the President and Congress. Probably the majority view is that, because Congress is expressly assigned the power to declare war, the President, except when repelling attacks, may not commit the United States to substantial military operations without congressional authorization. 52 Nevertheless, some scholars who otherwise agree with this majority view maintain that congressional authorization is not required, at least in many instances, when the United States is enforcing a Security Council resolution. ${ }^{53}$ Perhaps not surprisingly, some Presidents have also invoked this argument. President Truman did so, for example, in the Korean War, ${ }^{54}$ and the first President Bush did so in the Persian Gulf War. ${ }^{55}$ In effect, this argument would mean that, through the U.N. Charter, some of Congress's war authorization power has been delegated to the Security Council. Similar arguments have been made with respect to the NATO mutual defense treaty. ${ }^{56}$

Such a delegation of Congress's war power may be constitutionally questionable under both the formal and functional approaches to separation of powers. From a formal perspective, Article I assigns the War Declaration Power to Congress, and the Supreme Court has said that Congress may not ordinarily delegate away its powers. Furthermore, the U.N. Charter is a treaty, not a statute, and thus one of the two houses of Congress was not even involved

52. See, e.g., JOHN HART ELY, WAR AND RESPONSIBILITY: CONSTITUTIONAL LESSONS OF Vietnam and Its Aftermath (1993); Louis Fisher, Presidential War Power (1995); Francis D. Wormuth \& EdWIN B. Firmage, To Chain the Dog of War: The War Power OF CONGRESS IN HISTORY AND LAW (2d ed. 1989).

53. See, e.g., Thomas M. Franck \& Faiza Patel, UN Police Action in Lieu of War: "The Old Order Changeth," 85 AM. J. INT'L L. 63, 64, 67-69 (1991); David Golove, From Versailles to San Francisco: The Revolutionary Transformation of the War Powers, $70 \mathrm{U}$. CoLO. L. REv. 1491 (1999). But see Louis Fisher, Sidestepping Congress: Presidents Acting Under the UN and NATO, 47 CASE W. RES. L. REV. 1237 (1997); Michael J. Glennon, The Constitution and Chapter VII of the United Nations Charter, 85 AM. J. INT'L L. 74 (1991); Jane E. Stromseth, Rethinking War Powers: Congress, the President, and the United Nations, 81 GEO. L.J. 597 (1993).

54. See, e.g., Statement by the President on the Situation in Korea, 1950 PUB. PAPERS: HARRY S. TRUMAN 492 (June 27, 1950).

55. See, e.g., The President's News Conference on the Persian Gulf Crisis, 1991 PUB. PAPERS: GEORGE BUSH 20 (Jan. 9, 1991). President Bush subsequently received congressional authorization to use military force in the Persian Gulf War. See Pub. L. No. 102-1, 105 Stat. 3 (1991).

56. For example, President Clinton emphasized NATO's authorization of the use of force when he ordered U.S. forces to take part in the 1999 Kosovo bombing campaign. See, e.g., Address to the Nation on Airstrikes Against Serbian Targets in the Federal Republic of Yugoslavia (Serbia and Montenegro), 35 WKLY. COMP. PrES. DoC. 516 (Mar. 29, 1999). In a letter to Congress concerning the campaign, however, President Clinton invoked only his "constitutional authority to conduct U.S. foreign relations and as Commander in Chief and Chief Executive" and did not specifically claim that NATO's authorization enhanced his war powers. Letter to Congressional Leaders Reporting on Airstrikes Against Serbian Targets in the Federal Republic of Yugoslavia (Serbia and Montenegro), 35 WKLY. COMP. PreS. DoC. 527 (Mar. 29, 1999). 
in the purported delegation. In fact, the full Congress has, if anything, attempted to preclude this sort of delegation. ${ }^{57}$ From a functional perspective, it is far from clear that the Security Council is an adequate substitute for Congress in checking presidential uses of force. The Council does not purport to represent the interests of the U.S. electorate, and, although the United States has a veto power on the Council, the U.S. representative on the Council is appointed by, and subject to the direction of, the executive branch. ${ }^{58}$

\section{B. International Court of Justice}

The U.N. Charter also established the International Court of Justice (ICJ), which has jurisdiction to resolve international law disputes between nations. A member of the United Nations, such as the United States, is bound under the U.N. Charter to "comply with the decision of the International Court of Justice in any case to which it is a party." 59 The ICJ can only hear cases, however, in which both parties have consented in some fashion to the ICJ's jurisdiction. 60 For many years, the United States consented to the ICJ's general compulsory jurisdiction and thereby authorized the court to exercise jurisdiction over international law disputes between the United States and "any other state accepting the same obligation." 61 But in 1985, after the court exercised

57. In 1945, Congress enacted the United Nations Participation Act, 22 U.S.C.A. $\S \S 287-287$ e (West 2003). This Act authorizes the President to negotiate a special agreement with the United Nations for the use of U.S. forces, subject to congressional approval. Id. $\$ 287 \mathrm{~d}$. However, the President has never negotiated such an agreement, and the Act makes clear that "nothing herein contained shall be construed as an authorization to the President by the Congress to make available to the Security Council for such purpose armed forces, facilities, or assistance in addition to the forces, facilities, and assistance provided for in such special agreement or agreements." Id. At the end of the Vietnam War, Congress enacted the War Powers Resolution, 50 U.S.C.A. $\$ \S 1541-1548$ (West 2003). This Resolution states, among other things, that authorization to use force shall not be inferred "from any treaty heretofore or hereafter ratified unless such treaty is implemented by legislation specifically authorizing the introduction of United States Armed Forces into hostilities or into such situations and stating that it is intended to constitute specific statutory authorization within the meaning of this chapter." $I d$. $\S 1547(\mathrm{a})(2)$.

58. There may also be delegation concerns associated with placing U.S. forces under U.N. or NATO command. See, e.g., Michael J. Glennon \& Allison R. Hayward, Collective Security and the Constitution: Can the Commander in Chief Power Be Delegated to the United Nations?, 82 GEO. L.J. 1573 (1994); David Kaye, Are There Limits to Military Alliance? Presidential Power to Place American Troops Under Non-American Commanders, 5 Transnat'l L. \& ConTEMP. Probs. 399 (1995); John C. Yoo, Kosovo, War Powers, and the Multilateral Future, 148 U. PA. L. REv. 1673 (2000). But cf. Memorandum from Walter Dellinger to Alan J. Kreczko, Placing of United States Armed Forces Under United Nations Operational or Tactical Control (May 8, 1996) (arguing that Congress cannot restrict the President's authority to place U.S. forces under United Nations command), available at http://www.usdoj.gov/olc/hr3308.htm.

59. U.N. CHARTER, art. 94, para. 1.

60. See Statute of the International Court of Justice art. 36, 59 Stat. 1055 (1945).

61. Id. art. 36, para. 2. 
jurisdiction over a suit brought against the United States by Nicaragua, the United States withdrew its general consent. ${ }^{62}$ As a result, the United States can now be sued in the court only if it has consented to the ICJ's jurisdiction in a particular treaty with the complaining party or if it gives its specific consent to jurisdiction at the time the suit is filed. ${ }^{63}$ The United States continues to be a party, however, to a number of treaties that contain clauses authorizing the court to resolve disputes arising under the treaties.

As a general matter, U.S. participation in the ICJ would not seem to raise serious delegation concerns. The court applies only international law, not U.S. law; it hears only disputes between nations, not disputes involving private parties; and the cases heard by the ICJ are filed there in the first instance, which means that the court will not ordinarily review U.S. judicial decisions. Moreover, in terms of historical practice, the United States has participated in international arbitration and international claims settlement procedures throughout its history, dating back to the 1794 Jay Treaty. ${ }^{64}$ Furthermore, the United States has participated in the ICJ itself for more than fifty years. For these reasons, it is difficult to argue that it is unconstitutional for the United States to delegate interpretive authority to the ICJ concerning the United States's rights and duties under international law, at least if the international law materials being interpreted have been agreed to by the United States and are reasonably specific. 65

The ICJ's recent Breard and LaGrand decisions, however, suggest that the ICJ's decisionmaking will sometimes intersect with U.S. domestic practices in a way that can raise delegation concerns. These decisions involve U.S. obligations under the Vienna Convention on Consular Relations, which the United States ratified in 1969.66 Article 36 of the Convention provides that, when arresting foreign nationals from a country that is a party to the Convention, the arresting authorities shall inform them "without delay" that they have the right to have their consulate notified of their arrest and to

62. See Letter from George P. Schultz, Secretary of State of the United States of America, to Javier Perez de Cuellar, Secretary-General of the United Nations (Oct. 7, 1985), reprinted in 24 I.L.M. 1742 (1985). para. 1

63. See Statute of the InTERnational COURT OF Justice, supra note 60 , art. 36 ,

64. See Restatement (Third) of the Foreign Relations Law of the United States $\S 902$, reporters' note 8 (1987) [hereinafter RESTATEMENT (THIRD)] (discussing examples); Manley O. Hudson, International Tribunals: Past and Future 3-6 (1944) (same); A. Mark Weisburd, International Courts and American Courts, 21 MICH. J. INT'L L. 877, 89698 (2000) (same); see also Dames \& Moore v. Regan, 453 U.S. 654 (1981) (upholding transfer of claims to Iran-U.S. Claims Tribunal).

65. See HYDE, supra note $7, \S 504$, at 24 ("That the United States may constitutionally agree to refer to an international tribunal future controversies which may not prove to be susceptible of amicable adjustment by direct negotiation, is not to be doubted.").

66. See Vienna Convention on Consular Relations, Apr. 24, 1963, 21 U.S.T. 77 (ratified by the United States Nov. 24, 1969). 
communicate with their consulate. ${ }^{67}$ In Breard and LaGrand, foreign nationals had been convicted of murder and sentenced to death by state courts in the United States. The countries of which they were citizens (Paraguay in Breard and Germany in LaGrand) subsequently brought suit against the United States in the ICJ, arguing that the United States had violated the Vienna Convention because state authorities had failed to advise the foreign nationals of their right to consular notice. In both of these cases, the ICJ issued preliminary orders stating that the United States was to "take all measures at its disposal" to stay the executions while the court considered the claims. ${ }^{68}$ In response to these orders, neither Congress nor the executive branch attempted to compel the states to stop the executions, and the Supreme Court similarly refused to order a stay of execution. 69 Some commentators have nevertheless argued that the orders were binding on the United States and should have been enforced by U.S. authorities, including the Supreme Court. In effect, these commentators argue that the orders had the status of self-executing federal law that automatically superseded the relevant state law. ${ }^{70}$ Giving the orders this status, however, might raise serious delegation concerns, since the ICJ would be directly preempting state law within the U.S. legal system (and perhaps also overriding earlier inconsistent federal law concerning limits on habeas corpus relief). ${ }^{71}$

Subsequent developments in the LaGrand case further demonstrate the potential for conflict between decisions of the ICJ and U.S. domestic institutions. In Breard, Paraguay abandoned its case after its national was executed. In LaGrand, however, Germany did not abandon its case before the ICJ after its nationals were executed, and the ICJ subsequently issued a final decision in the case. In its decision, the ICJ held that the United States had

67. See id. art. 36, para. 1, 21 U.S.T. at 100.

68. See LaGrand Case (F.R.G. v. U.S.), 1999 I.C.J. 9, 16 (Mar. 3) (Request for the Indication of Provisional Measures); Vienna Convention on Consular Relations (Para. v. U.S.), 1998 I.C.J. 248, 258 (Apr. 9).

69. See Fed. Republic of Germany v. United States, 526 U.S. 111 (1999); Breard v. Greene, 523 U.S. 371 (1998).

70. See, e.g., Louis Henkin, Provisional Measures, U.S. Treaty Obligations, and the States, 92 AM. J. INT'L L. 679 (1998) (arguing that the ICJ order was binding and had the status of a self-executing treaty obligation); Anne-Marie Slaughter, Court to Court, 92 AM. J. INT'L L. 708 (1998) (arguing that the Supreme Court should have treated the ICJ order as self-executing federal law as a matter of jurisdictional comity); Carlos Manuel Vazquez, Breard and the Federal Power to Require Compliance with ICJ Orders of Provisional Measures, 92 AM. J. INT'L L. 683 (1998) (arguing that if the ICJ order was binding it had the status of self-executing federal law). In an amicus curiae brief filed in Breard, 12 international-law scholars urged the Supreme Court to grant a stay of execution in response to the ICJ's order. See Brief of Amici Curiae of International Law Professors, Breard (No. 97-1390).

71. For additional discussion of the Breard case, see Agora, Breard, 92 AM. J. INT'L L. 666-712 (1998); Curtis A. Bradley, Breard, Our Dualist Constitution, and the Internationalist Conception, 51 STAN. L. REV. 529 (1999); Weisburd, supra note 64, at 89296. 
violated the Vienna Convention; that the United States had also violated the ICJ's provisional order, which the ICJ held was legally binding; and that in future situations in which German nationals "have been subjected to prolonged detention or convicted and sentenced to severe penalties," the United States would be required "to allow the review and reconsideration of the conviction and sentence by taking account of the violation of the rights set forth in the Convention."72 The ICJ also stated, however, that "[t]his obligation can be carried out in various ways" and that " $t]$ he choice of means must be left to the United States." 73 Federal and state courts are now grappling with the issue of what weight, if any, to give to the ICJ's decision. ${ }^{74}$

\section{World Trade Organization}

The United States is a party to the World Trade Organization (WTO), which was established in 1995 to administer the General Agreement on Tariffs and Trade and related treaties. The WTO includes a Dispute Settlement Body (DSB), which uses appointed panels and a standing Appellate Body to adjudicate trade disputes between the member countries. ${ }^{75}$ The decisions adopted by the DSB are binding, and, if the losing party does not comply with a decision, the DSB may authorize the prevailing party to impose trade sanctions on the losing party. ${ }^{76}$ The United States has already participated in numerous cases presented to the DSB, both as a complaining party and as a defending party. As a defendant, the United States has lost several significant cases, including a case challenging clean air regulations issued by the Environmental Protection Agency, a case challenging U.S. limits on shrimp imports designed

72. LaGrand Case (F.R.G. v. U.S.), 2001 I.C.J. 466 (June 27), reprinted in 40 I.L.M. $1069,1096,1100(2001)$.

73. Id. at 1100 .

74. Compare Valdez v. State, 46 P.3d 703, 709 (Okla. Crim. App. 2002) ("For this court to decide the ICJ's ruling [in LaGrand] overrules a binding decision of the United States Supreme Court and affords a judicial remedy to an individual for a violation of the [Vienna] Convention would interfere with the nation's foreign affairs and run afoul of the U.S. Constitution."), and Bell v. Commonwealth, 563 S.E.2d 695, 706 (Va. 2002) ("[W]e conclude that the ICJ [in LaGrand] . . . did not hold that Article 36 of the Vienna Convention creates legally enforceable individual rights that a defendant may assert in a state criminal proceeding to reverse a conviction."), with United States ex rel. Madej v. Schomig, $223 \mathrm{~F}$. Supp. 2d 968, 978 (N.D. Ill. 2002) ("This Court agrees with Petitioner, that LaGrand does foreclose strict reliance on procedural default rules for violations of the Vienna Convention."), and United States ex rel. Madej v. Schomig, No. 98 C 1866, 2002 U.S. Dist. LEXIS 20170, at *3 (N.D. Ill. Oct. 22, 2002) (accepting the "conclusive determination from the I.C.J. [in LaGrand], whose mandate it is to interpret the Vienna Convention, that the Vienna Convention confers individual rights").

75. See Understanding on Rules and Procedures Governing the Settlement of Disputes, Apr. 15, 1994, Marrakesh Agreement Establishing the World Trade Organization [hereinafter WTO Agreement], Annex 2, Legal InSTRUMENTS-RESULTS OF THE URUGUAY RouND vol. 31, 33 I.L.M. 1226, 1226-27 (1994).

76. $I d$. art 22 . 
to protect sea turtles, and a case challenging U.S. tax treatment of foreign sales corporations. ${ }^{77}$ The WTO's DSB is thus reviewing the validity of, and ordering changes to, U.S. domestic laws that affect international trade.

The rulemaking powers of the WTO may raise additional delegation concerns. The WTO has the power to adopt binding interpretations of the various trade agreements by a three-fourth's vote, and thus in theory can adopt an interpretation over the United States's dissent. ${ }^{78}$ Many of the obligations in the trade agreements contain broad principles rather than specific requirements, such as a prohibition on "arbitrary or unjustifiable discrimination."79 The WTO's interpretations therefore could, in effect, create new obligations for the United States not foreseeable at the time that it ratified the relevant treaties. If so, it could be argued that the United States has delegated to an international institution part of the Article II treaty power vested in the President and Senate. ${ }^{80}$ Even when the new interpretations are adopted with U.S. consent, one might still conclude that Congress's role in the international agreement process is being evaded, since the U.S. representative in the WTO is a representative of the executive, not legislative, branch. ${ }^{81}$ Although the nondelegation doctrine has not been enforced vigorously with respect to domestic delegations (such as delegations to administrative agencies), it is arguable that international delegations, like the one to the WTO, should be subject to greater scrutiny because the institutions exercising rulemaking authority do not possess independent constitutional power and are less accountable than domestic officials to the U.S. electorate. ${ }^{82}$

77. See WTO Appellate Body Report: United States-Tax Treatment for "Foreign Sales Corporations" (Recourse to Article 21.5 of the DSU by the European Communities) (Jan. 14, 2002), reprinted in 41 I.L.M. 447 (2002); WTO Appellate Body Report: United States-Import Prohibition of Certain Shrimp and Shrimp Products (Recourse to Article 21.5 of the DSU by Malaysia) (Oct. 22, 2001), reprinted in 41 I.L.M. 149 (2002); WTO Appellate Body Report: United States-Standards for Reformulated and Conventional Gasoline (May 20, 1996), reprinted in 35 I.L.M. 603 (1996).

78. See General Agreement on Tariffs and Trade: Multilateral Trade Negotiations Final Act Embodying the Results of the Uruguay Round of Trade, art. IX(2), 33 I.L.M. 1125 (1994). Other international institutions, such as the International Monetary Fund, have similar rulemaking procedures. See Stephan, supra note 3, at 685.

79. See, e.g., General Agreement on Tariffs and Trade: Basic Agreements, Oct. 30, 1947 , art. XX, T.I.A.S. 1700, 55 U.N.T.S. 187.

80. For additional discussion of this point, see $\mathrm{Ku}$, supra note 1, at 96-98. But cf. John O. McGinnis \& Mark L. Movsesian, The World Trade Constitution, 114 HARV. L. REV. 511 (2000) (arguing that the WTO does not currently pose a threat to sovereignty or representative democracy and that it can in fact promote democracy).

81. As noted above, the informal participation of nongovernmental organizations also complicates the picture. See supra note 4.

82. The addition of new members to the WTO may also raise delegation concerns, since the executive branch is not required to obtain congressional or senatorial consent before agreeing to such additions, even though such additions will by definition change the United States's treaty relationships. See Lawrence M. Reich, Foreign Policy or Foreign Commerce?: WTO Accessions and the U.S. Separation of Powers, 86 GEO. L.J. 751 (1998). 


\section{NAFTA}

In 1993, the United States became a party, along with Canada and Mexico, to the North American Free Trade Agreement (NAFTA). ${ }^{83}$ Chapter 19 of NAFTA allows import decisions of the member countries concerning antidumping and countervailing duties to be reviewed by binational arbitral panels. These panels apply the standard of review and substantive law that would be applied by the importing country's own courts, and the panels' decisions are final and binding. ${ }^{84}$ In the case of the United States, the panels exercise review over the application of U.S. trade law by the Commerce Department and the International Trade Commission, whose decisions otherwise would be subject to review by the Court of International Trade, an Article III court. ${ }^{85}$ By statute, U.S. agencies are required to comply with decisions of the panels, and no judicial review of the panel decisions is allowed.86 At least some of the panel members, however, will not be Article III judges. Nor is their selection subject to the Article II appointments process. ${ }^{87}$ While there is certainly precedent for international arbitration of

Congress did play an important role in helping to facilitate China's efforts to join the World Trade Organization, by voting in 2000 to approve permanent normal trade relations with China. See Matthew Vita, Senate Approves Normalized Trade with China, 83-15, WASH. PosT, Sept. 20, 2000, at A1. But the 1999 agreement between the United States and China, concerning the conditions under which the United States would support China's entry into the World Trade Organization, was concluded without formal participation by Congress. See Erik Eckholm \& David E. Sanger, The Trade Deal: The Overview; U.S. Reaches an Accord to Open China Economy as Worldwide Market, N.Y. TIMES, Nov. 16, 1999, at A1.

83. See North American Free Trade Agreement, Dec. 8, 1992, Can.-Mex.-U.S., 32 I.L.M. 289 [hereinafter NAFTA].

84. Id. art. 1904.

85. The decisions of the Court of International Trade could in turn be reviewed by the United States Court of Appeals for the Federal Circuit and by the Supreme Court.

86. 19 U.S.C.A. $\S 1516 \mathrm{a}(\mathrm{g})(7)(A)$ (West 2003). The panel decisions can be reviewed by an "extraordinary challenge committee" on certain narrow grounds, such as gross misconduct, bias, or conflict of interest. See NAFTA, supra note 83, art. 1904(13), annex 1904.13. Also, although the panel decisions cannot be challenged in a U.S. court, the constitutionality of the binational panel scheme itself can be challenged in the U.S. Court of Appeals for the D.C. Circuit. See 19 U.S.C.A. $\$ 1516 \mathrm{a}(\mathrm{g})(2),(\mathrm{g})(4)(\mathrm{A})$ (West 2003). Even if the scheme is found to be unconstitutional, however, the President has statutory discretion "to accept, as a whole, the decision of a binational panel," in which case the International Trade Commission shall "take action not inconsistent with such decision." Id. $\S 1516 \mathrm{a}(\mathrm{g})(7)(\mathrm{B})$.

87. Panel members are selected by the parties in the dispute from a roster of individuals developed by the three NAFTA countries, which "shall include sitting or retired judges to the fullest extent practicable." NAFTA, supra note 83, annex 1901.2(1). At least two of the five members of the NAFTA binational panels (and in many cases three) will not be Article III judges and will not be subject to the Article II appointments process. In fact, it is arguable that none of the members will be appointed consistent with Article II, either because they are principal rather than inferior officers (who must be appointed by the President rather than a head of a department), or because the United States Trade Representative is not a head of a department. This scheme was challenged in the D.C. 
claims involving the United States and U.S. citizens, the NAFTA panels appear to be unique in that they apply U.S. law and exercise direct review over U.S. administrative decisions. 88

Another feature of NAFTA that may raise delegation concerns is Chapter 11 , which requires each country to afford investors of the other two countries certain minimum standards of treatment, including protection against uncompensated expropriation, as well as nondiscriminatory treatment. Investors who allege a violation of Chapter 11 may submit claims to a panel of three private arbitrators who can award monetary damages but not injunctive relief. Recently, a NAFTA arbitration panel held, in a case filed by a Canadian company against the United States, that a decision by a Mississippi trial court could itself constitute an expropriation and thus can be challenged under Chapter 11.89 In a similar case, a Canadian company filed an action against the United States for alleged expropriation after the Massachusetts Supreme Judicial Court dismissed its breach of contract suit against the City of Boston on sovereign immunity grounds. ${ }^{90}$ Although the arbitral panel eventually held in favor of the United States in this second case, it did so only after carefully reviewing the Massachusetts court's reasoning. ${ }^{91}$ As a result, NAFTA is being used, at least indirectly, to conduct international review of the fairness and outcome of U.S. judicial decisions. ${ }^{92}$

Circuit on various delegation grounds, but the plaintiff (a trade association) was found to lack standing, so the D.C. Circuit did not address the delegation issues. See Am. Coalition for Competitive Trade v. Clinton, 128 F.3d 761 (D.C. Cir. 1997). For discussion of the constitutionality of this scheme, see Ethan Boyer, Article III, the Foreign Relations Power, and the Binational Panel System of NAFTA, 13 INT'L TAX \& BUS. L. 101 (1996); Demetrios G. Metropoulos, Constitutional Dimensions of the North American Free Trade Agreement, 27 CoRnell INT'L L.J. 141 (1994); Note, Matthew Burton, Assigning the Judicial Power to International Tribunals: NAFTA Binational Panels and Foreign Affairs Flexibility, 88 VA. L. REV. 1529 (2002).

88. The international arbitral tribunal at issue in Dames \& Moore v. Regan, 453 U.S. 654 (1981), is distinguishable. That case concerned the Iran-United States Claims Tribunal, which considers claims against government entities rather than private parties, is not obligated to apply a particular nation's domestic law, and does not exercise direct review over domestic decisions.

89. See Decision on Hearing of Respondent's Objection to Competence and Jurisdiction, Loewen Group, Inc. v. United States (ICSID Jan. 5, 2001) (No. ARB(AF)/98/3), available at http:/www.state.gov/documents/organization/3921 pdf.

90. See Notice of Arbitration, Mondev Int'l Ltd. v. United States (ICSID Sept. 1, 1999), available at http://www.state.gov/documents/organization/3931.pdf.

91. See Award, Mondev Int'l Ltd. v. United States 7 129-140 (ICSID Oct. 11, 2002) (No. ARB(AF)/99/2), available at http:/www.state.gov/documents/organization/14442.pdf.

92. For a discussion of these cases, see Charles H. Brower II, Investor-State Disputes Under NAFTA: The Empire Strikes Back, 40 ColUM. J. TRANSNAT'L L. 43, 51-61 (2001). For additional information on the Chapter 11 NAFTA cases that have been brought against the United States, see U.S. Dep't of State, NAFTA Investor-State Arbitrations, at http://www.state.gov/s/l/c3439.htm. 
To be clear, there may not be anything shocking about the idea that judicial decisions can constitute an expropriation. ${ }^{93}$ Normally, however, concerns about judicial expropriation have been addressed in the United States through appellate review and through application of the Fifth and Fourteenth Amendments' Due Process Clauses. It is a new development to use non-U.S. adjudicators and international law to directly review the fairness of U.S. litigation. ${ }^{94}$ In addition, it is not clear that the President or Congress anticipated that U.S. litigation, especially litigation between purely private parties, would be subject to review in this way when they agreed to NAFTA. ${ }^{95}$ As a result, the NAFTA decisions may be an illustration of how the jurisdictional authority of international institutions tends to expand over time. ${ }^{96}$

93. See Paul B. Stephan, Redistributive Litigation-Judicial Innovation, Private Expectations, and the Shadow of International Law, 88 VA. L. REV. 789 (2002) (suggesting that the concept of expropriation should sometimes apply to judicial decisionmaking).

94. The 1794 Jay Treaty provided for compensation of British creditors who could not recover on their claims "by the ordinary course of judicial proceedings," but the treaty did not provide for direct review of U.S. judicial decisions. See Jay Treaty, supra note 7, art. 6. Also, unlike the other two arbitral commissions established by the Jay Treaty, the British debts commission became mired in procedural and jurisdictional controversy and never decided any cases. Instead, the British debts issue was eventually settled by means of a lump-sum payment, combined with an assurance that creditors on both sides would not meet with lawful impediments to the recovery of debts. See SAMUEL FlaGg Bemis, JAY's TreatY 438-39 (1962).

95. NAFTA refers to "measures adopted or maintained by a party," and it defines "measure" to include "any law, regulation, procedure, requirement or practice." NAFTA, supra note 83, arts. 201, 1101(1). In its initial brief in Loewen, the U.S. government argued that "there is no support in international case law for the proposition that a civil court judgment entering money damages against a foreign investor in a private dispute can constitute an expropriation." Counter-Memorial of the United States of America, Loewen Group, Inc. v. United States đ181 (ICSID March 30, 2001) (No. ARB(AF)/98/3), available at http://www.state.gov/documents/organization/7387.pdf.

96. Another example of this phenomenon is the Inter-American Commission on Human Rights, based in Washington, D.C. The Commission was established in 1959 to "promote the observance and protection of human rights and to serve as a consultative organ of the Organization [of American States] in these matters." Organization of American States: Charter Signed at Bogota, art. 106, 2 U.S.T. 2394, 119 U.N.T.S. 3 (1948) (entered into force Dec. 13, 1951). The Commission was not established as a court and was not given the power to adjudicate disputes. Nevertheless, the Commission has increasingly acted like a court, issuing a variety of adjudicatory rulings. For example, the Commission has issued a number of decisions concerning the validity under international law of the U.S. death penalty. See, e.g., Case 12.285 (Domingues v. U.S), Inter-Am. C.H.R., No. 62/02 (Oct. 22, 2002), available at http://www.cidh.org/annualrep/2002eng/USA.12285.htm (concluding that the United States would violate international law if it executed an individual who was under 18 years of age when he committed his offense). The United States has not joined the Inter-American Court of Human Rights, based in Costa Rica. Nevertheless, that institution has also issued rulings concerning the United States, through the use of advisory opinions. See, e.g., El Derecho a la Información Sobre la Asistencia Consular en el Marco de las Garantías del Debido Proceso Legal [The Right to Information on Consular Assistance in the Framework of the Guarantees of the Due Process of Law], Advisory Opinion OC-16/99, Oct. 1, 1999, Inter-Am. Ct. H.R. (Ser. A) No. 16 (concluding that execution of an individual who had not been advised of his right to consular notification would violate due process). 


\section{E. Chemical Weapons Convention}

In 1997, the United States ratified the Chemical Weapons Convention, which banned the development, retention, and use of chemical weapons. The Convention further established a new international organization, the Organization for the Prohibition of Chemical Weapons, which has the power to verify Convention compliance by ordering inspections of public and private facilities in the United States. Inspections are conducted by the Organization's Technical Secretariat, members of which are not appointed by or removable by U.S. officials. It is arguable that the delegation of inspection authority to these members violates the requirements of the Appointments Clause. ${ }^{97}$ These searches may also raise Fourth Amendment concerns. 98 The legislation implementing the Convention attempts to address some of these constitutional concerns by, for example, requiring that employees of the federal government accompany the Technical Secretariat officials on their inspections, limiting the scope of the inspections, and providing for the issuance of search warrants. 99

\section{F. International Criminal Court}

In 1998,120 nations agreed on the text of a treaty that would establish a permanent International Criminal Court. The treaty, entitled the Rome Statute of the International Criminal Court, took effect in July 2002 after it had been ratified by sixty nations. Under the treaty, an international court, based in the

97. See John C. Yoo, The New Sovereignty and the Old Constitution: The Chemical Weapons Convention and the Appointments Clause, 15 CONST. COMMENT. 87 (1998). For an early and important discussion of the constitutional issues associated with arms control inspection, see LOUIS HENKIN, ARMS CONTROL AND INSPECTION IN AMERICAN LAW (1958).

98. See Robert F. Greenlee, The Fourth Amendment and Facilities Inspections Under the Chemical Weapons Convention, 65 U. CHI. L. REV. 943 (1998); Jonathan P. Hersey \& Anthony F. Ventura, Challenging Challenge Inspections: A Fourth Amendment Analysis of the Chemical Weapons Convention, 25 FlA. ST. U. L. REV. 570 (1998); Ronald D. Rotunda, The Chemical Weapons Convention: Political and Constitutional Issues, 15 ConsT. COMMENT. 131 (1998).

99. See Chemical Weapons Convention Implementation Act of 1998, Pub. L. No. 105277, 112 Stat. 2681 (codified at 22 U.S.C. $\$ \S 6701-6771$ ). Recently, the U.S. government raised constitutional concerns with respect to a different inspection regime. A proposed Optional Protocol to the Convention Against Torture and Other Cruel, Inhuman and Degrading Treatment or Punishment, if approved by the United States, would allow international monitors to inspect state prisons. In explaining U.S. opposition to the proposed Protocol, a U.S. representative stated that the "overall approach and certain specific provisions [of the draft Protocol] are contrary to our Constitution, particularly with respect to matters of search and seizure," and that, "in view of our Federal system of government, the regime established by the draft would be overly intrusive." John Davison, Deputy U.S. Representative on the United Nations Econ. \& Soc. Council, Explanation of Vote on the Optional Protocol to the Convention Against Torture and Other Cruel, Inhuman and Degrading Treatment or Punishment (July 24, 2002), available at http://www.state.gov/p/io/ $\mathrm{rls} / \mathrm{rm} / 2002 / 12200$ htm; see also Barbara Crossette, U.S. Fails in Effort to Block Vote on U.N. Convention on Torture, N.Y. TIMES, July 25, 2002, at A7. 
Hague, will have jurisdiction to try the offenses of genocide, crimes against humanity, war crimes, and the crime of aggression. Despite expressing a number of concerns about the treaty, President Clinton signed it shortly before leaving office. The Bush administration informed the United Nations in 2002, however, that the United States has no intention of ratifying the treaty. ${ }^{100}$ If the United States did become a party to the treaty, the court would have jurisdiction to try U.S. citizens for the covered offenses, even if committed in the United States. ${ }^{101}$ In trying these offenses, the court would apply the terms of the treaty, other applicable treaties, "rules of international law, including the established principles of the international law of armed conflict," and, as a last resort, "general principles of law derived by the Court from national laws of legal systems of the world including, as appropriate, the national laws of States that would normally exercise jurisdiction over the crime."102 As a party to the treaty, the United States would be required to "cooperate fully with the Court in its investigation and prosecution of crimes within the jurisdiction of the Court," and to "comply with requests for arrest and surrender."103 Some commentators have argued that the extent of the International Criminal Court's jurisdiction is such that U.S. participation in the court would violate the constitutional limits on non-Article III tribunals. ${ }^{104}$

100. See Press Release, International Criminal Court: Letter to U.N. Secretary General Kofi Annan, available at http://www.state.gov/r/pa/prs/ps/2002/9968.htm.

101. Even if the United States does not become a party to the treaty, the court will purportedly have jurisdiction to try U.S. citizens for offenses committed in the territory of nations that are parties to the treaty. See Rome Statute of the International Criminal Court, art. 12(2), July 17, 1998, U.N. Doc. A/CONF. 183/9, 37 I.L.M. 999 [hereinafter Rome Statute]. The court's jurisdiction is subject, however, to the principle of "complementarity," whereby the court will not adjudicate a case that is "being investigated or prosecuted by a State which has jurisdiction over it, unless the State is unwilling or unable genuinely to carry out the investigation or prosecution." Id. art. 17(1)(a). Nevertheless, the Bush administration has suggested that the United States may not participate in United Nations peacekeeping operations without an assurance of immunity from prosecution for U.S. troops. See Serge Schmemann, U.S. Links Peacekeeping to Immunity from New Court, N.Y. TIMES, June 19, 2002, at A3. In July 2002, the Security Council granted U.S. peacekeepers a oneyear immunity from prosecution before the International Criminal Court. The Bush administration has also sought to negotiate agreements with individual countries whereby U.S. soldiers and government employees would not be extradited to the court. See Elizabeth Becker, U.S. Presses for Total Exemption from War Crimes Court, N.Y. TIMES, Oct. 9, 2002, at A6. In addition, in August 2002, Congress enacted the American Servicemembers' Protection Act, which prohibits U.S. assistance to the International Criminal Court and insists that U.S. soldiers not participate in U.N. peacekeeping operations if they face a risk of prosecution before the court. See American Servicemembers' Protection Act, Pub. L. 107206, 116 Stat. 820, tit. II. The Act also authorizes the President to use "all means necessary and appropriate" to obtain the release of U.S. and allied soldiers and government employees detained or imprisoned by the court. $1 d$. $\$ 2008$ (a).

102. Rome Statute, supra note 101, art. 21(1).

103. Id. arts. $86,89(1)$.

104. See, e.g., Lee A. Casey, The Case Against the International Criminal Court, 25 FORDHAM INT'L L.J. 840 (2002); see also SENATE COMM. ON FOREIGN RELATIONS, International Criminal CourT, S. Rep. No. 71, 103d Cong., 1st Sess. (1993) (containing 


\section{G. Customary International Law}

Another example raising delegation concerns, albeit one that does not involve an international institution per se, is the claim that customary international law - the law of the international community that "results from a general and consistent practice of states followed by them from a sense of legal obligation"105_has the status within the United States of self-executing federal common law. 106 This is a claim that has received widespread support in the international-law academy, ${ }^{107}$ as well as endorsement by a number of courts. ${ }^{108}$ If this claim were correct, it would mean that federal courts would have the authority to apply norms developed by the international community to preempt inconsistent state law, and possibly also executive branch or congressional

report from the Judicial Conference of the United States raising constitutional concerns); ABA TASK FORCE ON AN INT'L CRIMINAL COURT, ESTABLISHMENT OF AN INTERNATIONAL CRIMINAL COURT, reprinted in 27 INT'L LAW 257 (1993) (raising constitutional concerns). But see Audrey I. Benison, International Criminal Tribunals: Is There a Substantive Limitation on the Treaty Power?, 37 STAN. J. INT'L L. 75 (2001) (arguing that U.S. participation in the Court would be constitutional); Paul D. Marquardt, Law Without Borders: The Constitutionality of an International Criminal Court, 33 CoLUM. J. TRANSNAT'L L. 73 (1995) (same). The United States has already statutorily committed itself to extradite suspects to the ad hoc international criminal tribunals established for former Yugoslavia and for Rwanda. See National Defense Authorization Act for Fiscal Year 1996, Pub. L. No. 104-106, $\S 1342,110$ Stat. 186, 486; see also Ntakirutimana v. Reno, 184 F.3d 419 (5th Cir. 1999) (upholding extradition to the Rwandan tribunal).

105. RESTATEMENT (THIRD), supra note $64, \S 102(2)$.

106. There is in fact some connection between this example and international institutions, since it is often claimed that modern customary international law derives, at least in part, from the nonbinding pronouncements, resolutions, and actions of international institutions, such as the United Nations General Assembly. See, e.g., id. § 102, reporters' note 2 ("The practice of states that build customary law takes many forms and includes what states do in or through international organizations.").

107. See, e.g., id. § 111; Louis Henkin, International Law as Law in the United States, 82 MICH. L. REV. 1555 (1984); Harold Hongju Koh, Is International Law Really State Law?, 111 Harv. L. Rev. 1824 (1998); Beth Stephens, The Law of Our Land: Customary International Law as Federal Law After Erie, 66 FORDHAM L. REv. 393 (1997).

108. See, e.g., Kadic v. Karadzic, 70 F.3d 232, 246 (2d Cir. 1995); In re Estate of Ferdinand E. Marcos Human Rights Litig., 978 F.2d 493, 502 (9th Cir. 1992); Filartiga v. Pena-Irala, 630 F.2d 876, 885 (2d Cir. 1980); Xuncax v. Gramajo, 886 F. Supp. 162, 193 (D. Mass. 1995). But cf. Sampson v. Fed. Republic of Germany, 250 F.3d 1145, 1153 n.4 (7th Cir. 2001) (noting the "present uncertainty about the precise domestic role of customary international law"). For a critique of the federal common law claim, see Curtis A. Bradley \& Jack L. Goldsmith, Customary International Law as Federal Common Law: A Critique of the Modern Position, 110 HARV. L. Rev. 815 (1997) [hereinafter Bradley \& Goldsmith, Customary International Law]; Curtis A. Bradley \& Jack L. Goldsmith, Federal Courts and the Incorporation of International Law, 111 HARV. L. REV. 2260 (1998); see also Odah v. United States, 321 F.3d 1134, 1147-48 (D.C. Cir. 2003) (Randolph, J., concurring) (questioning the proposition that customary international law has the status of federal common law). 
action. ${ }^{109}$ From a formal perspective, this argument is problematic because customary international law does not seem to fit within the Supremacy Clause's list of federal law: It is neither a treaty nor the Constitution, and it is not "made in Pursuance" of the Constitution, as required by the Supremacy Clause for "Laws of the United States." 110 From a functional perspective, this argument is problematic because it would give unelected federal judges broad lawmaking authority not stemming from any political branch authorization, in areas in which they may have limited institutional competence. ${ }^{111}$

The Alien Tort Statute (also sometimes referred to as the Alien Tort Claims Act) implicates a related delegation issue. That statute, first enacted in 1789, provides that "[ $t]$ he district courts shall have original jurisdiction of any civil action by an alien for a tort only, committed in violation of the law of nations or a treaty of the United States."112 In recent years, courts have held that, in addition to conferring jurisdiction on the federal courts, the statute creates a private cause of action for any violation of an alien's rights under the "law of nations," the historic term for a body of unwritten law that included customary international law.113 Courts also have held that the reference to the law of nations is a reference to an evolving body of customary international law, such that courts should apply the customary international law that exists at the time of the case rather than the customary international law that existed at the time the statute was enacted. ${ }^{114}$ If this twofold construction of the statute is correct, ${ }^{115}$ it would mean that Congress has delegated to the federal courts the power to apply, as federal statutory law, changing rules of unwritten

109. See, e.g., Lea Brilmayer, Federalism, State Authority, and the Preemptive Power of International Law, 1994 SUP. CT. REV. 295; Louis Henkin, The Constitution and United States Sovereignty: A Century of Chinese Exclusion and Its Progeny, 100 HARV. L. REV. 853 (1987); Jules Lobel, The Limits of Constitutional Power: Conflicts Between Foreign Policy and International Law, 71 VA. L. REV. 1071 (1985).

110. See U.S. CONST. art. VI, cl. 2 ("This Constitution, and the Laws of the United States which shall be made in Pursuance thereof; and all Treaties made, or which shall be made, under the Authority of the United States, shall be the supreme Law of the Land ....").

111. For additional discussion of the functional concerns associated with treating customary international law (especially modern customary international law) as federal common law, see Bradley \& Goldsmith, Customary International Law, supra note 108, at $861-70$.

112. 28 U.S.C.A. § 1350 (West 2003).

113. See, e.g., In re Estate of Ferdinand E. Marcos, 25 F.3d at 1474-75; Xuncax, 886 F. Supp. at 179; see also Tel-Oren v. Libyan Arab Republic, 726 F.2d 774, 780 (D.C. Cir. 1984) (Edwards, J., concurring) (asserting that "section 1350 itself provides a right to sue for alleged violations of the law of nations").

114. See, e.g., Filartiga v. Pena-Irala, 630 F.2d 876, 881 (2d Cir. 1980).

115. For evidence indicating that the First Congress did not view the Statute as creating a private cause of action, see Curtis A. Bradley; The Alien Tort Statute and Article III, 42 VA. J. INT'L L. 587; 592-97 (2002). For a suggestion that the Statute's reference to the law of nations may be limited to the types of international law offenses recognized in 1789 , see Tel-Oren, 726 F.2d at 812-16 (Bork, J., concurring). 
international law. 116 Unlike other forms of domestic common law, these rules are not developed in the specific context of U.S. practices, culture, and institutions. This delegation might be especially problematic with respect to modern customary international law, the sources and content of which are radically different from the customary international law that existed in 1789.117

Given the nature of the relevant constitutional doctrines, the validity of particular relationships with international institutions would have to be determined on an individual basis, with careful scrutiny of the type and scope of authority exercised by the institutions. The important point for now is that the United States's relationship with these institutions implicates nonfrivolous delegation concerns of the sort taken seriously in domestic cases. Indeed, if anything, the delegation concerns may be greater in this context because international actors will tend to be less accountable to the U.S. electorate than domestic governmental actors. 118

\section{FOREIGN AFFAIRS EXCEPTIONALISM}

The most obvious counterargument to the above discussion is what I have called "foreign affairs exceptionalism." 19 Foreign affairs exceptionalism is the idea that foreign affairs powers should be subject to different, and generally

116. One could argue that the modern construction of the Alien Tort Statute merely makes the statute a federal choice of law provision, akin to the Rules of Decision Act, which directs the federal courts to apply state law as the rule of decision "except where the Constitution or treaties of the United States or Acts of Congress otherwise require or provide." 28 U.S.C.A. $\S 1652$ (West 2003). But the Rules of Decision Act does not create a federal statutory cause of action for violations of state law, and, in any event, it may be more problematic to delegate the content of federal law to the "international community" than to state governments. But of. United States v. Smith, 18 U.S. (5 Wheat.) 153, 157 (1820) (upholding, as sufficiently precise, a criminal statute punishing "the crime of piracy, as defined by the law of nations"). Furthermore, if the Alien Tort Statute's reference to the law of nations is merely a choice of law and jurisdictional provision, suits between aliens under the statute may not fall within any of the cases or controversies set forth in Article III of the Constitution. See Bradley, supra note 115 (explaining this point).

117. Among other things, whereas traditional customary international law was purportedly based on the longstanding practices of nations, modern customary international law is derived at least in part from the views expressed by nations in international institutions. In addition, whereas traditional customary international law regulated primarily the relations between nations, modern customary international law also regulates the relationship between nations and their own citizens. See generally Bradley \& Goldsmith, Customary International Law, supra note 108, at 838-42; J. Patrick Kelly, The Twilight of Customary International Law, 40 VA. J. INT'L L. 449 (2000).

118. See supra note 3 and accompanying text.

119. See, e.g., Bradley, supra note 71, at 555-56; Curtis A. Bradley, A New American Foreign Affairs Law?, 70 U. COLO. L. REv. 1089 (1999). 
more relaxed, constitutional restraints than domestic powers. The case for foreign affairs exceptionalism is primarily a functional one-grounded, for example, in concerns about the need for flexibility in addressing foreign affairs problems and the desirability of speaking with "one voice" in interacting with the international community. Doctrinally, this idea draws support from certain Supreme Court decisions issued in the 1920s through the 1940s. 120

With respect to delegation concerns, the most relevant Supreme Court decision is United States v. Curtiss-Wright Export Corp. ${ }^{121}$ In that case, Congress passed a joint resolution authorizing the President to prohibit the sale of arms to countries involved in a conflict in Latin America (and thereby subject such sales to criminal punishment) if he found that such a prohibition would "contribute to the reestablishment of peace between those countries."122 In upholding the constitutionality of this delegation of authority, the Court, in an opinion by Justice Sutherland, assumed for the sake of argument that the delegation would be unconstitutional if it concerned domestic affairs. The Court reasoned that there are "differences between the powers of the federal government in respect of foreign or external affairs and those in respect of domestic or internal affairs," and it stated that these differences are "fundamental." 23 In explaining these differences, the Court claimed that "[t]he broad statement that the federal government can exercise no powers except those specifically enumerated in the Constitution, and such implied powers as are necessary and proper to carry into effect the enumerated powers, is categorically true only in respect of our internal affairs." 124 The Court also emphasized presidential supremacy in foreign affairs, stating that "[i]n this vast external realm, with its important, complicated, delicate and manifold problems, the President alone has the power to speak or listen as a representative of the nation."125

The Court's analysis in Curtiss-Wright, especially its analysis of Founding history, has been heavily criticized by academic commentators. ${ }^{126}$ As

120. See, e.g., United States v. Belmont, 301 U.S. 324 (1937); United States v. CurtissWright Exp. Corp., 299 U.S. 304 (1936); Missouri v. Holland, 252 U.S. 416 (1920). See generally G. Edward White, The Transformation of the Constitutional Regime of Foreign Relations, 85 VA. L. REV. 1 (1999).

121. 299 U.S. 304 (1936).

122. Id. at 312 .

123. Id. at 315 .

124. Id. at 315-16.

125. Id. at 319.

126. See, e.g., Thomas M. Franck, Political Questions, Judicial Answers: Does THE Rule of LAW APPLY to Foreign AfFaIRS? 14-18 (1992); Michael J. Glennon, Two Views of Presidential Foreign Affairs Power: Little v. Barreme or Curtiss-Wright?, 13 YALE J. INT'L L. 5 (1988); David M. Levitan, The Foreign Relations Power: An Analysis of Mr. Justice Sutherland's Theory, 55 YALE L.J. 467 (1946); Charles A. Lofgren, United States v. Curtiss-Wright Export Corporation: An Historical Reassessment, 83 YALE L.J. 1 (1973); Michael D. Ramsey, The Myth of Extraconstitutional Foreign Affairs Power, 42 WM. \& Mary L. Rev. 379 (2000); see also Harold HongJu Koh, The National Security 
Professor Henkin notes, the proposition that "the new United States government was to have major powers outside the Constitution is not intimated in the Constitution itself, in the records of the [Federal] Convention, in the Federalist Papers, or in contemporary debates." 127 This proposition also appears to be at odds with the modern Supreme Court's frequent description of the national government as one of limited and enumerated powers. ${ }^{128}$ Commentators have further argued that the Court's sweeping statements in Curtiss-Wright about presidential power are inconsistent with both separation of powers and the rule of law. 129

In any event, there are a number of reasons why Curtiss-Wright does not eliminate the constitutional concerns posed by U.S. involvement with international institutions. Despite some broad statements in the opinion, the actual holding of Curtiss-Wright concerns only the nondelegation doctrine, and the Court did not consider other constitutional limits on delegation. As discussed above, the nondelegation doctrine is not much of a restraint today even in the domestic arena, so relaxing that doctrine for foreign affairs would not have much effect on the contemporary constitutional analysis. In addition, Curtiss-Wright concerned a delegation within the U.S. system, between Congress and the President, not an international delegation. ${ }^{130}$ The Court therefore was not confronted with the constitutional issues posed by international delegations. In addition, Justice Sutherland's ultimate concernensuring that the national government has sufficient "powers of external sovereignty," so that it is "completely sovereign" $\mid 31$ - may in fact be in tension with international delegations, which often entail limitations on the national government's authority.

As a result, it would take a significant expansion of Curtiss-Wright to overcome the constitutional concerns posed by international delegations. It is difficult to justify such an expansion, either on formal or functional grounds. As a formal matter, the constitutional provisions that relate to delegations-for example, the vesting of particular powers in particular branches, the

CONSTITUTION: SHARING POWER AFTER THE IRAN-CONTRA AFFAIR 94 (1990) (describing the "withering criticism" of Curtiss-Wright).

127. HENKIN, supra note 1, at 19-20.

128. See, e.g., United States v. Morrison, 529 U.S. 598, 669 (2000); Alden v. Maine, 527 U.S. 706, 713 (1999); City of Boerne v. Flores, 521 U.S. 507, 516 (1997); United States v. Lopez, 514 U.S. 549, 566 (1995).

129. See, e.g., $\mathrm{KOH}$, supra note 126 , at $94-95$.

130. This is how subsequent Supreme Court decisions have referred to Curtiss-Wright. For example, in the Line Item Veto Act case, the Court cited and quoted Curtiss-Wright, stating that "this Court has recognized that in the foreign affairs arena, the President has "a degree of discretion and freedom from statutory restriction which would not be admissible were domestic affairs alone involved." Clinton v. City of New York, 524 U.S. 417, 445 (1998). The Court has also relied on Curtiss-Wright more generally for the proposition that courts should give deference to the executive branch in the area of foreign affairs. See, e.g., Regan v. Wald, 468 U.S. 222, 243 (1984).

131. United States v. Curtiss-Wright Exp. Corp., 299 U.S. 304, 318 (1936). 
requirements of the Appointments Clause, and the terms of Article III-make no distinction between foreign and domestic affairs. Moreover, the foreign affairs provisions of the Constitution are prime illustrations of the Founders' efforts to limit aggrandizements of power, both through process limitations and through divisions of responsibility. The Treaty Power, for example, is divided between the President and Senate, and is subject to supermajority approval. ${ }^{132}$ And the War Power is divided between the President and Congress. ${ }^{133}$ The text of the Constitution thus suggests that foreign affairs powers are not immune from the Constitution's structural safeguards.

The functional case for foreign affairs exceptionalism is also weak in this context. Although there may be good functional arguments for international delegations, such as the need to address collective action problems, they are not the flexibility and one-voice arguments underlying foreign affairs exceptionalism. International delegations, by potentially binding the United States ex ante to rules and decisions it has not specifically approved, may in fact reduce the case-by-case flexibility often thought important in foreign affairs. Even if the United States has the ability to withdraw from institutions if it disagrees with such rules or decisions, such exit is likely to be costly and sometimes practically unavailable. 134 In addition, the argument for one voice in foreign relations assumes that this voice will be exercised by accountable U.S. actors, not by international decisionmakers. The functional case for foreign affairs exceptionalism also assumes a bright-line distinction between foreign and domestic affairs, a distinction that is difficult to maintain in the context of international delegations, since international institutions increasingly address issues that formerly were of only domestic concern.

It is also worth noting that, to the extent there is scholarly support for the idea of foreign affairs exceptionalism, this support exists primarily with respect to federalism limitations, not separation of powers limitations. A number of commentators have maintained that constitutional restraints based on federalism apply with less force, or not at all, in the area of foreign affairs. But

132. See U.S. Const. art. II, $\S 2$, cl. 2 (granting the President, "by and with the Advice and Consent of the Senate, to make Treaties, provided two thirds of the Senators present concur").

133. See id. art. I, $\S 8$, cls. 11-14 (granting Congress the powers to "declare War" and to regulate the armed forces); id. art. II, $\S 2$, cl. 1 (making the President the "Commander in Chief" of the armed forces).

134. According to the Vienna Convention on the Law of Treaties, a nation can withdraw from a treaty only if either (1) the treaty explicitly or implicitly allows for withdrawal, or (2) all parties to the treaty consent to the withdrawal. See Vienna Convention on the Law of Treaties, opened for signature May 23, 1969, arts. 54-56, 1155 U.N.T.S. 331, 340, 8 I.L.M. 679, 691-92 (1969). Treaties that explicitly provide for withdrawal often specify a notice period. For example, the treaty establishing the World Trade Organization requires six-months' notice for withdrawal. See WTO Agreement art. XV. Some treaties have been construed not to allow for withdrawal. See, e.g., General Comment 26, U.N. GAOR Hum. Rts. Comm., 53rd Sess., Supp. No. 40, I 5, U.N. Doc. A/53/40 (1998) (construing the International Covenant on Civil and Political Rights). 
these same commentators accept the possibility of separation of powers restrictions on the exercise of foreign affairs powers. For example, despite vigorously contesting the applicability of federalism-based restrictions on the treaty power, Professor David Golove notes that treaties are "in principle subject to the separation of powers restrictions which are applicable to ordinary acts of Congress." 135 Similarly, Professor Henkin states that "[t]he Treaty Power . . . is not limited to the powers of Congress, but it is assumed to be subject to other radiations from the separation of powers."136

Nevertheless, it must be acknowledged that there is a long history of judicial avoidance and abstention in foreign affairs. ${ }^{137}$ Although courts have often stated that treaties are subject to the Constitution, they have never invalidated a treaty on constitutional grounds. They also frequently invoke standing, ripeness, political question, and other procedural limitations to avoid reaching the merits of foreign affairs cases. ${ }^{138}$ In addition, they frequently defer to the executive branch's position in foreign affairs cases-for example, giving "great weight" to the executive branch's construction of a treaty. 139 They also tend to defer to institutional arrangements worked out by the political branches to regulate foreign affairs, such as the use of congressional-executive agreements. ${ }^{140}$ Furthermore, even in the domestic context, the constitutional limitations on delegation are often complex and uncertain-such as the limitations on the use of non-Article III courts. ${ }^{141}$ As a result, it seems likely that courts will be reluctant to exercise direct constitutional review over international delegations and that they will seek instead to address delegation concerns through their interpretation of treaties and international decisions. With this in mind, the next Part discusses a possible interpretive approach.

135. Golove, supra note 47 , at 1084. But of. Golove, supra note 2, at 1699-701 (suggesting that international delegations are not subject to the limitations applicable to domestic delegations).

136. HENKIN, supra note 1, at 195.

137. See, e.g., FRANCK, supra note 126; KoH, supra note 126, ch. 6.

138. See, e.g., Goldwater v. Carter, 444 U.S. 996 (1979) (declining to decide the validity of President Carter's unilateral termination of defense treaty with Taiwan); Made in the USA Found. v. United States, 242 F.3d 1300 (11th Cir. 2001) (declining to decide the constitutionality of using a congressional-executive agreement for NAFTA).

139. See, e.g., Sumitomo Shoji Am., Inc. v. Avagliano, 457 U.S. 176, 185 (1982); Kolovrat v. Oregon, 366 U.S. 187, 194 (1961); see also El Al Israel Airlines, Ltd. v. Tsui Yuan Tseng, 525 U.S. 155, 168 (1999) ("Respect is ordinarily due the reasonable views of the Executive Branch concerning the meaning of an international treaty."). See generally Curtis A. Bradley, Chevron Deference and Foreign Affairs, 86 VA. L. REV. 649 (2000) (discussing this and other deference doctrines).

140. See, e.g., Weinberger v. Rossi, 456 U.S. 25 (1982) (interpreting the word "treaty" in an employment discrimination statute as referring not only to Article II treaties but also congressional-executive agreements).

141. See supra text accompanying notes 30-35. 


\section{NON-SELF-EXECUTION}

At least some of the delegation concerns discussed above can be addressed by presuming that the decisions and rulings of international institutions are "non-self-executing"- that is, that they do not create enforceable federal law unless and until they are implemented by Congress. ${ }^{142}$ This distinction between self-executing and non-self-executing obligations has long been reflected in U.S. treaty law. The Supremacy Clause makes clear that treaties can override inconsistent state law, and it has been construed to mean that treaties also can override earlier federal statutes (a component of what is sometimes referred to as the "last-in-time rule"). ${ }^{143}$ Although the clause could be read to suggest that all U.S. treaties have these effects, U.S. courts have recognized a distinction between self-executing and non-self-executing treaties. Only self-executing treaties, courts have held, constitute judicially enforceable federal law. ${ }^{144}$ Although non-self-executing treaties are binding on the United States, they are not enforceable in U.S. courts and do not by themselves override federal statutes or state laws. Courts have held, for example, that provisions of the U.N. Charter-a treaty that indisputably binds the United States internationally - are not self-executing and are thus not enforceable in U.S. courts. ${ }^{145}$

142. This approach is consistent with what international law theorists refer to as "dualism," pursuant to which international law and domestic law are treated as distinct, the nation determines for itself when and to what extent international law is incorporated into its legal system, and the status of international law within the legal system is determined by domestic law. See Bradley, supra note 71, at 530-31 (explaining the distinction between monist and dualist approaches to the relationship between international law and domestic law).

143. See, e.g., Cook v. United States, 288 U.S. 102 (1933). There is more authority for the other component of the last-in-time rule-that is, that federal statutes can override earlier treaties. See, e.g., Breard v. Greene, 523 U.S. 371, 376 (1998); Chae Chan Ping v. United States (The Chinese Exclusion Case), 130 U.S. 581, 600-01 (1889); Whitney v. Robertson, 124 U.S. 190, 194 (1888); Edye v. Robertson (The Head Money Cases), 112 U.S. 580, $597-$ 98 (1884). That component of the last-in-time rule is based in part on delegation concerns. As the Court explained in The Chinese Exclusion Case, "[t] delegated in trust to the United States, and are incapable of transfer to any other parties." 130 U.S. at 609.

144. See, e.g., Foster v. Neilson, 27 U.S. (2 Pet.) 253, 314 (1829) (stating that if a treaty is not self-executing, "the legislature must execute the [treaty], before it can become a rule for the court"); United States v. Duarte-Acero, 296 F.3d 1277, 1283 (11th Cir. 2002) ("Treaties affect United States law only if they are self-executing or otherwise given effect by congressional legislation."); Beazley v. Johnson, 242 F.3d 248, 267 (5th Cir. 2001) ("Non-self-executing" means that absent any further actions by the Congress to incorporate them into domestic law, the courts may not enforce them."' (quoting Jama v. INS, 22 F. Supp. 2d 353, 365 (D.N.J. 1998)); see also RESTATEMENT (THIRD), supra note 64, $\S 111(3)$ ("[A] 'non-self-executing' agreement will not be given effect as law in the absence of necessary implementation.").

145. See, e.g., Frolova v. Union of Soviet Socialist Republics, 761 F.2d 370, 374 (7th Cir. 1985); Spiess v. C. Itoh \& Co. (Am.), 643 F.2d 353, 363 (5th Cir. 1981); Sei Fujii v. State, 242 P.2d 617, 620-22 (Cal. 1952). 
There is, to be sure, academic debate about the proper scope of the nonself-execution doctrine as applied to treaties. For example, commentators have debated whether courts should presume that treaties are self-executing or nonself-executing. ${ }^{146}$ The case law is uncertain on that issue, although the trend in recent years appears to support a presumption against self-execution, especially for multilateral treaties. ${ }^{147}$ There is also debate concerning the precise meaning of "non-self-execution." The prevailing view in the courts is that non-selfexecuting treaties are not judicially enforceable. ${ }^{148}$ Some scholars have argued, however, that non-self-executing treaties may simply lack a private right of action and that these treaties can and should be enforced by courts in situations not requiring a private right of action, such as in criminal cases or in civil cases in which some other law provides a right to sue. ${ }^{149}$

To some extent, these debates can be bypassed here, since I am invoking the non-self-execution doctrine only by analogy. The academic arguments in support of both a presumption in favor of self-execution and a limited scope to non-self-execution stem primarily from the Supremacy Clause, which provides that "all" treaties "shall" be the "supreme Law of the Land." 150 While I think scholars are wrong to equate "supreme Law of the Land" with automatic

146. Compare John C. Yoo, Globalism and the Constitution: Treaties, Non-SelfExecution, and the Original Understanding, 99 ColuM. L. REv. 1955 (1999), and John C. Yoo, Treaties and Public Lawmaking: A Textual and Structural Defense of Non-SelfExecution, 99 Colum. L. REV. 2218 (1999), with Martin S. Flaherty, History Right?: Historical Scholarship, Original Understanding, and Treaties as "Supreme Law of the Land," 99 ColuM. L. REV. 2095 (1999), and Carlos Manuel Vazquez, Laughing at Treaties, 99 Colum. L. Rev. 2154 (1999).

147. See, e.g., Goldstar (Panama) S.A. v. United States, 967 F.2d 965, 968 (4th Cir. 1992); More v. Intelcom Support Servs., Inc., 960 F.2d 466, 469 (5th Cir. 1992); Frolova, 761 F.2d at 373. But see Beharry v. Reno, 183 F. Supp. 2d 584, 593 (S.D.N.Y. 2002) ("Treaties are generally treated as self-executing, that is, they are enforceable in courts once signed and ratified."). Even in cases in which courts have found (or assumed) a treaty to be self-executing, they have often been reluctant to provide relief to individual claimants, especially when such relief is opposed by the executive branch. Recent cases denying relief under the consular notice provisions of the Vienna Convention on Consular Relations are a good illustration of this phenomenon. See, e.g., Duarte-Acero, 296 F.3d at 1277; United States v. De La Pava, 268 F.3d 157 (2d Cir. 2001); United States v. Li, 206 F.3d 56 (1st Cir. 2000).

148. See supra note 144.

149. See, e.g., David Sloss, Non-Self-Executing Treaties: Exposing a Constitutional Fallacy, 36 U.C. DAVIS L. REV. 1 (2002). Professor Sloss goes so far as to suggest that, because of the Supremacy Clause, the Senate and President lack the constitutional power to preclude judicial enforcement of certain treaties. See id. at 15-16. As Jack Goldsmith and I have argued elsewhere, this argument reflects a misconception of the Supremacy Clause. See Curtis A. Bradley \& Jack L. Goldsmith, Treaties, Human Rights, and Conditional Consent, 149 U. PA. L. REV. 399, 446-49 (2000). Among other things, the Clause's reference to treaties was designed to enhance the federal government's ability to ensure state compliance with treaties, not to restrict the federal government's flexibility in deciding whether and how to comply with international law. See id. at 448-49.

150. U.S. CONST. art. VI, cl. 2. 
judicial enforceability, the decisions and actions of international institutions are, in any event, not directly encompassed within the Supremacy Clause. They are not themselves "treaties," nor do they fall within the other two categories of supreme federal law-the "Constitution" and "Laws of the United States ... made in Pursuance [of the Constitution]."151 At best, these actions and decisions are indirectly linked to the Supremacy Clause by virtue of some underlying treaty commitment to the international institution. But those commitments typically involve only a promise of compliance and do not purport to convert the decisions and actions of international institutions into self-executing federal law.

Another argument that is sometimes made in this context is that non-selfexecution is suspect because some treaties confer individual rights under international law, and it is impermissible for a treaty to mean one thing internationally and something else domestically. ${ }^{152}$ This argument may be a non sequitur, since non-self-execution does not change the international law obligations imposed by a treaty; rather, it simply means that U.S. compliance with the treaty will not be enforced directly by U.S. courts. ${ }^{153}$ In any event, it is simply wrong to claim that there can be no divergence between the meaning of a treaty on the international plane and its meaning in the U.S. legal system. There are in fact a variety of U.S. doctrines, some of them quite settled, that can create such a divergence. For example, U.S. courts will attempt to construe treaties so that they do not conflict with the Constitution. 154 Similarly, they will attempt to construe treaties to avoid a conflict with a federal statute. ${ }^{155}$ The Supreme Court has even suggested that, for federalism reasons, treaties

151. Id.

152. See David Sloss, International Decisions: United States v. Duarte-Acero, 97 AM. J. INT'L L. (forthcoming 2003); see also JOHN NORTON MOORE, TREATY INTERPRETATION, THE CONSTITUTION AND THE RULE OF LAW (2001) (arguing that there should be a "unitary" rather than "dual" standard of treaty interpretation).

153. See supra note 144 .

154. See generally CONG. Research SERV., TREaties aNd Other INTERnational AGREEMENTS: THE ROLE OF THE UNITED STATES SENATE 70-71 (2001) ("Whatever specific constitutional limitations may be deemed applicable to the treaty power in a given case, the courts, in lieu of express declarations of unconstitutionality, evidence a proclivity merely to refuse full effectuation of specific treaty provisions that might offend constitutional requirements."). In effect, these decisions apply the Ashwander canon of construction, pursuant to which U.S. courts will attempt to avoid the unnecessary resolution of constitutional issues. See Ashwander v. Tenn. Valley Auth., 297 U.S. 288, 348 (1936) (Brandeis, J., concurring). If there is an unavoidable conflict between a treaty and the Constitution, U.S. courts will apply the Constitution. See, e.g., Boos v. Barry, 485 U.S. 312, 324 (1988); Reid v. Covert, 354 U.S. 1, 16-19 (1957) (plurality opinion).

155. See, e.g., Johnson v. Browne, 205 U.S. 309, 321 (1907); United States v. Lee Yen Tai, 185 U.S. 213, 222 (1902); Blanco v. United States, 775 F.2d 53, 61 (2d Cir. 1985); see also Baker v. Carr, 369 U.S. 186, 212 (1962) (noting that "a court will not undertake to construe a treaty in a manner inconsistent with a subsequent federal statute"). If there is an unavoidable conflict between a treaty and a federal statute, U.S. courts will apply the enactment that is later in time. See supra note 143. 
should be presumed not to preempt state law.156 Furthermore, as noted above, U.S. courts often give "great weight" to the executive branch's construction of treaties, ${ }^{157}$ and they tend to rely more heavily on drafting history in interpreting treaties than would an international court. ${ }^{158}$ These and other interpretive doctrines confirm that there can indeed be divergences between the international and domestic meanings of a treaty.

In any event, as even critics of non-self-execution acknowledge, the Constitution's distribution of federal powers has long been thought to be relevant to the self-execution analysis. ${ }^{159}$ Thus, for example, treaty provisions calling for the appropriation of money have been treated as non-self-executing in order to preserve Congress's constitutional authority over appropriations. ${ }^{160}$ Similarly, treaties modifying tariff duties have generally been treated as nonself-executing in order to preserve the House of Representatives's role in raising revenue. ${ }^{161}$ For somewhat different reasons (relating to notice and the Supreme Court's rejection in the early 1800 s of a federal common law of crimes), it has generally been assumed that treaties calling for the criminalization of conduct are non-self-executing-that is, they do not themselves create criminal liability within the United States. ${ }^{162}$ It is also often

156. See, e.g., Guar. Trust Co. v. United States, 304 U.S. 126, 143 (1938) ("Even the language of a treaty wherever reasonably possible will be construed so as not to override state laws or to impair rights arising under them."); see also Arthur R. Kuhn, The TreatyMaking Power and the Reserved Sovereignty of the States, 7 COLUM. L. REV. 172, 181 \& n.2 (1907) ("The power of the courts to 'interpret' treaty provisions so as to make them consistent with the police or reserved powers of a State has been exercised on [several] occasions." (citing Prevost v. Greneaux, 60 U.S. (19 How.) 1 (1856); Cantini v. Tillman, 54 F. 969 (1893); People v. Dibble, 16 N.Y. 203 (1857), aff'd, 62 U.S. (21 How.) 366 (1858))).

157. See supra note 139.

158. See, e.g., Sale v. Haitian Ctrs. Council, Inc., 509 U.S. 155, 184-87 (1993); INS v. Cardoza-Fonseca, 480 U.S. 421, $437-39$ (1987); RESTATEMENT (THIRD), supra note 64, $\S 325$, cmt. g \& reporters' note 4 .

159. See generally Edwards v. Carter, 580 F.2d 1055, 1057-59 (D.C. Cir. 1978); RESTATEMENT (THIRD), supra note $64, \S 111 \mathrm{cmt}$. i; HENKIN, supra note 1, at 203; WRIGHT, supra note 7 , at 354-56.

160. See Turner v. Am. Baptist Missionary Union, 24 F. Cas. 344, 345-46 (C.C.D. Mich. 1852); Samuel B. Crandall, Treaties: Their Making and Enforcement 164-82 (2d ed. 1916); Quincy Wright, Treaties and the Constitutional Separation of Powers in the United States, 12 AM. J. INT'L L. 64, $65-67$ (1918); see also U.S. CONST. art. I, § 9, cl. 7 ("No Money shall be drawn from the Treasury, but in Consequence of Appropriations made by Law ....").

161. See Edwards, 580 F.2d at 1058 n.15; see also U.S. ConST. art. 1, § 7, cl. 1 ("All Bills for raising Revenue shall originate in the House of Representatives."); CrANDALL, supra note 160 , at $183-99$.

162. See, e.g., Hopson v. Kreps, 622 F.2d 1375, 1380 (9th Cir. 1980); United States v. Postal, 589 F.2d 862, 877 (5th Cir. 1979); The Over the Top, 5 F.2d 838, 845 (D. Conn. 1925). But see Edwin D. Dickinson, Are the Liquor Treaties Self Executing?, 20 AM. J. INT'L L. 444, 449-50 (1926) (questioning this proposition). Tariff agreements often take the form of congressional-executive agreements so that the House of Representatives is included directly in the process. 
said that, because only the full Congress has the constitutional power to declare war, a treaty cannot, by itself, place the United States into a state of war. ${ }^{163}$ If anything, the argument for non-self-execution is stronger in the context of international delegations, where the power in question has been assigned away from the entire Congress (and in some instances future presidents as well), not just the House of Representatives.

Applying the non-self-execution approach to international decisions and rulings would mean that they would bind the United States internationally, but Congress or the treatymakers would need to implement the decisions or rulings before they would alter U.S. domestic law or become enforceable in U.S. courts. For example, if the U.N. Security Council authorized the use of military force, this authorization might affect the United States's rights and duties under international law, but it would not by itself satisfy the constitutional requirements for the use of force. Similarly, if an international adjudicatory body entered an order concerning the propriety of U.S. conduct or litigation, the order would not by itself change the law to be applied in U.S. courts. The non-self-execution approach would further suggest that customary international law does not of its own force have the status of enforceable federal law.

This has in fact been the approach that courts have intuitively followed when confronted with delegation concerns. In Diggs $v$. Richardson, ${ }^{164}$ for example, the Security Council had issued a resolution calling upon all nations to cease certain relationships with South Africa, because of its occupation of the former U.N. territory of Namibia. Relying on this resolution, a group of plaintiffs sought declaratory and injunctive relief prohibiting the U.S. government from continuing to deal with South Africa concerning the importation of seal furs from Namibia. ${ }^{165}$ The D.C. Circuit upheld dismissal of the lawsuit, concluding that the Security Council's resolution was not selfexecuting. 166 The court noted, among other things, that the resolution was not addressed to the judicial branch, did not by its terms confer individual rights, addressed foreign relations issues within the discretion of the executive branch, and did not provide specific standards for adjudication. ${ }^{167}$ The court further observed that, in treating the resolution as non-self-executing, the court was able to

avoid the larger questions raised by this case: under what circumstances a Security Council resolution can create a binding international obligation on the United States; whether Article 25 of the UN Charter, in which the member

\footnotetext{
163. See Edwards, 580 F.2d at 1058 n.7.

164. 555 F.2d 848 (D.C. Cir. 1976).

165. Id. at 849 .

166. Id. at 850 \& n.9.

167. Id. at 851 .
} 
nations agree to carry out the resolutions of the Council, can ever give rise to a self-executing resolution; and so on. 168

The D.C. Circuit followed a similar approach in Committee of United States Citizens Living in Nicaragua v. Reagan. ${ }^{169}$ In that case, various plaintiffs challenged the United States's failure to abide by a decision of the International Court of Justice holding that the United States was "under a duty immediately to cease and to refrain" from assisting the contra rebel forces in Nicaragua. ${ }^{170}$ The court rejected this challenge for two reasons. First, it concluded that, under the last-in-time rule, Congress had effectively overridden the United States's obligation to comply with the ICJ's decision, since Congress had continued to authorize assistance to the contras after the decision had been issued. ${ }^{171}$ Second, citing its earlier decision in Diggs, the court concluded that the U.N. Charter obligation to comply with decisions of the ICJ was not self-executing. 172 The court noted, among other things, that "the purpose of establishing the ICJ was to resolve disputes between national governments," not to "vest citizens who reside in a U.N. member nation with authority to enforce an ICJ decision against their own government." 173

The Supreme Court also implicitly used the non-self-execution approach in the Breard case discussed above. ${ }^{174}$ The Court's decision took the form of a short per curiam opinion that was issued without oral argument and under substantial time pressure, and the opinion does not expressly address the status of the ICJ's preliminary order. The opinion does state, however, that

while we should give respectful consideration to the interpretation of an international treaty rendered by an international court with jurisdiction to interpret such, it has been recognized in international law that, absent a clear and express statement to the contrary, the procedural rules of the forum State govern the implementation of the treaty in that State. ${ }^{175}$

Moreover, the opinion relies on the last-in-time rule, holding that a 1996 habeas corpus statute took precedence over the earlier ratified Vienna Convention on Consular Relations. ${ }^{176}$ This analysis implicitly declines to treat the order of the ICJ (which was later in time than the habeas statute) as having independent status as federal law.

The U.S. treatymakers also are increasingly using the non-self-execution approach to ensure that international obligations are filtered through the U.S.

168. Id. at 850 n.9.

169. 859 F.2d 929 (D.C. Cir. 1988).

170. Id. at 931 (citing Military and Paramilitary Activities (Nicar, v. U.S.), 1986 I.C.J. $14,146,149)$.

171. Id. at $936-37$.

172. Id. at $937-38$.

173. Id. at 938 .

174. See supra notes $66-74$ and accompanying text.

175. Breard v. Greene, 523 U.S. 371, 375 (1998) (per curiam).

176. See id. at 376 . 
legislative process before they change U.S. domestic law. In ratifying a number of treaties in recent years, especially in the human rights area, the President and Senate have attached declarations stating that none of the substantive terms of the treaties shall be considered self-executing. ${ }^{177}$ Among other things, these declarations ensure that interpretations of the treaties by the international institutions established under the treaties will not by themselves operate as U.S. domestic law. ${ }^{178}$ To take one recent example, the Human Rights Committee established under the International Covenant on Civil and Political Rights has issued "comments" suggesting that the execution of juvenile offenders violates U.S. obligations under the Covenant, even though the Senate and President expressly declined to agree to a prohibition on such executions when ratifying the Covenant. 179 To date, courts have found that the

177. See, e.g., U.S. Senate Resolution of Advice and Consent to Ratification of the Convention on the Elimination of All Forms of Racial Discrimination, 103d Cong., 2d Sess., 140 CONG. REC. S7634 (daily ed. June 24, 1994); U.S. Senate Resolution of Advice and Consent to Ratification of the International Covenant on Civil and Political Rights, 102d Cong., 2d Sess., 138 CONG. REC. S4783 (daily ed. Apr. 2, 1992); U.S. Senate Resolution of Advice and Consent to Ratification of the Convention Against Torture and Other Cruel, Inhuman or Degrading Treatment or Punishment, 101st Cong., 2d Sess., 136 CONG. REC. S17491 (daily ed. Oct. 27, 1990). In connection with the Genocide Convention, the U.S. treatymakers did not attach a non-self-execution declaration; instead, they specified that the United States would not deposit its instrument of ratification with the United Nations until Congress enacted implementing legislation. See U.S. Senate Resolution of Advice and Consent to Ratification of the Convention on the Prevention and Punishment of the Crime of Genocide, 99th Cong., 2d Sess., 132 Cong. Rec. S1378 (daily ed. Feb. 19, 1986).

178. Professor Sloss has argued that, in attaching the non-self-execution declarations to their ratification of the human rights treaties, the Senate and President intended merely to preclude a private right of action under the treaties, not to preclude other uses of the treaties in U.S. courts. See David Sloss, The Domestication of International Human Rights: NonSelf-Executing Declarations and Human Rights Treaties, 24 YALE J. INT'L L. 129 (1999). There are numerous statements in the ratification history of the treaties, however, explaining that the non-self-execution declarations would preclude all judicial enforcement of the treaties. See Bradley \& Goldsmith, supra note 149, at 419-22 (documenting this point). These statements are consistent with the justifications offered by the Senate and President for the non-self-execution declarations: that existing U.S. law already satisfied the requirements of the treaties, making direct judicial enforcement of the treaties unnecessary; that direct judicial enforcement of the treaties would have a destabilizing effect on domestic rights protections; and that changes in domestic rights protections should come from Congress. See id. at 419-20. Although Professor Sloss correctly notes that there are statements in the ratification history explaining that the non-self-execution declarations would preclude a private right of action, there is no evidence that the Senate and President meant by these statements to allow for judicial enforcement of the treaties in situations not requiring a private right of action. To date, courts have construed the non-self-execution declarations as precluding all judicial enforcement of the treaties. See, e.g., United States v. Duarte-Acero, 296 F.3d 1277, 1283 (11 th Cir. 2002) (holding, on direct appeal in a criminal case, that relief was not available under a non-self-executing treaty because the treaty "does not create judicially-enforceable individual rights"); Buell v. Mitchell, 274 F.3d 337, 372 (6th Cir. 2001) (holding that non-self-executing treaties do not provide basis for habeas corpus relief because they are not "binding on federal courts").

179. See Comments on United States of America, U.N. GAOR Hum. Rts. Comm., 50th Sess., I 279, U.N. Doc. CCPR/C/79/Add.50 (1995) ("The Committee is also particularly 
non-self-execution declaration precludes a challenge to state death penalty laws based on the Committee's comments. ${ }^{180}$

Congress also has played an important role in limiting the domestic effect of international decisions and rulings. As noted above, Congress has attempted to do this with respect to Security Council authorizations of the use of force. ${ }^{181}$ It also imposed warrant requirements and other procedural limitations on the inspections authorized by the Chemical Weapons Convention. In addition, Congress followed a non-self-execution approach in implementing the WTO trade agreements. The implementing legislation for these agreements states that "[n]o provision of [the agreements], nor the application of any such provision to any person or circumstance, that is inconsistent with any law of the United States shall have effect," and that the agreements may not be enforced in a U.S. court against a state "except in an action brought by the United States for the purpose of declaring such law or application invalid."182 Furthermore, Congress approved a Statement of Administrative Action, which provides that WTO decisions "have no binding effect under the law of the United States and do not represent an expression of U.S. foreign or trade policy,"183 and Congress's implementing legislation states that the Statement of Administrative Action "shall be regarded as an authoritative expression by the United States concerning the interpretation and application of the [WTO] Agreements and this Act in any judicial proceeding in which a question arises concerning such interpretation or application."184 Congress thus has made clear that domestic

concerned at reservations to article 6 , paragraph 5 [which prohibits the execution of juvenile offenders], and article 7 of the Covenant, which it believes to be incompatible with the object and purpose of the Covenant."); General Comment 24, U.N. GAOR Hum. Rts. Comm., 49th Sess., If 18, U.N. Doc. CCPR/C/21/Rev.1/Add.6 (1994) ("The normal consequence of an unacceptable reservation is not that the Covenant will not be in effect at all for a reserving party. Rather, such a reservation will generally be severable, in the sense that the Covenant will be operative for the reserving party without benefit of the reservation."). In approving the Covenant, the Senate and President included with the U.S. instrument of ratification a reservation expressly stating that the United States was not agreeing to the Covenant's prohibition on the execution of juvenile offenders. See 138 Cong. Rec. S4783 ๆ I (2).

180. See, e.g., Beazley v. Johnson, 242 F.3d 248, 267-68 (5th Cir. 2001). For a broader discussion of the international law issues relating to the execution of juvenile offenders, see Curtis A. Bradley, The Juvenile Death Penalty and International Law, 52 DUKE L.J. 485 (2002).

181. See supra note 57.

182. 19 U.S.C.A. §3512(a)(1), (b)(2)(A) (West 2003); see also Turtle Island Restoration Network v. Evans, 284 F.3d 1282, 1303 (Fed. Cir. 2002) (Newman, J., dissenting) (noting that "no party asserts that WTO decisions have controlling status as United States law").

183. H.R. Doc. 103-316, 103d Cong., 2d Sess. 1032 (1994); see also 19 U.S.C.A. $\S 3511$ (a)(2) (West 2003) (approving the Statement).

184. 19 U.S.C.A. $\S 3512$ (d) (West 2003). 
political actors must accept and implement WTO decisions before they alter state or federal law. 185

As international institutions exercise increasing degrees of authority over matters that traditionally have been regulated by U.S. domestic law, these nonself-execution filters-whether imposed by the courts, the treatymakers, or Congress - are likely to become even more common. These filters may not address all the delegation concerns associated with U.S. participation in international institutions, but they will tend to reduce many of these concerns. In addition, these filters are likely to be easier for courts to administer than imposing direct constitutional restraints on international delegations. ${ }^{186}$

\section{CONCLUSION}

Despite its isolationist reputation, the United States has steadily increased its involvement with international institutions. In doing so, it has delegated a variety of powers to these institutions-powers to adjudicate disputes, to make rules and standards, and to take or authorize enforcement measures. These institutions, in turn, have displayed an unsurprising tendency to interpret their delegated powers more expansively over time. Although international delegations are far from per se unconstitutional, they do raise what I have called delegation concerns. These concerns are similar to, and in some ways more pronounced than, the delegation concerns at issue in domestic transfers of authority.

Given the practical and doctrinal limitations on judicial review in this area, an interpretive approach may be the most realistic means of enforcing constitutional limitations on international delegations. This Article proposes one such approach-treating the decisions and actions of international institutions as non-self-executing within the U.S. legal system. This non-self-

185. Congress also considered but did not enact legislation that would establish a "WTO Dispute Panel Review Board," made up of U.S. judges, to review WTO decisions adverse to the United States. See NAFTA Renegotiation and WTO Dispute Settlement Review Commission Act, H.R. 78, 105th Cong., 1st Sess. (1997); WTO Dispute Settlement Review Commission Act, S. 1438, 104th Cong., 1st Sess. (1995).

186. The non-self-execution approach is not made less attractive by the fact that Congress generally has the power to override international decisions for purposes of U.S. law. See Golove, supra note 2, at 1741. Congress can override many domestic delegations as well, but that has not rendered irrelevant the constitutional limitations discussed in Part I. Furthermore, political and resource constraints, and institutional inertia more generally, often make it difficult for Congress to override the status quo. In any event, it is not always Congress's institutional interests that are at stake. For example, with respect to adjudicative delegations, it is the federal judiciary's interests that are at stake, and there is no reason to assume that Congress will act affirmatively to protect those interests. 
execution approach will reduce many of the constitutional concerns associated with international delegations without significantly affecting the United States's ability to participate in international institutions. Perhaps for that reason, U.S. courts have intuitively followed this approach, and the political branches have increasingly incorporated it into treaties and statutes. 